\title{
On the Efficiency of US Electricity Usage since 1900
}

Robert U. Ayres (ayres@iiasa.ac.at)

Leslie W. Ayres (leslie.ayres @ insead.edu)

Vladimir Pokrovsky (vpok@ waldonet.net.mt)

\section{Approved by}

Leen Hordijk

Director, International Institute for Applied Systems Analysis

June 30, 2004 Institute, its National Member Organizations, or other organizations supporting the work. 


\section{Contents}

1. Background ................................................................................................. 1

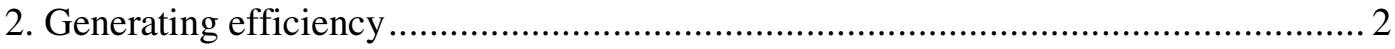

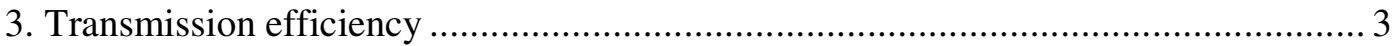

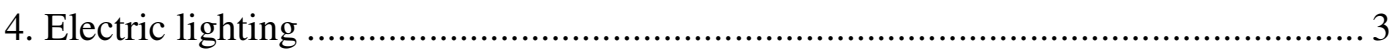

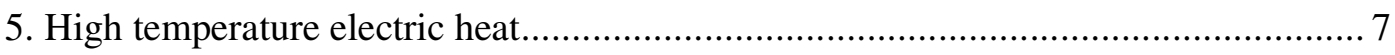

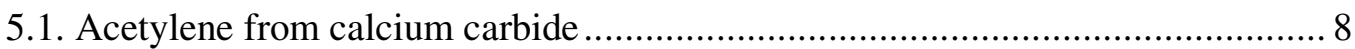

5.2. Phosphoric acid by the furnace process. ..................................................... 9

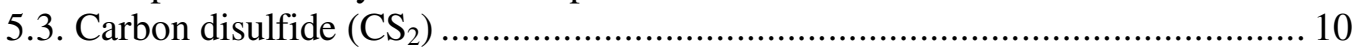

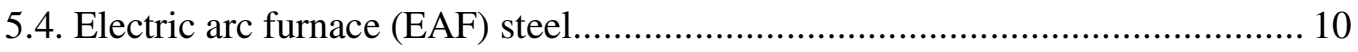

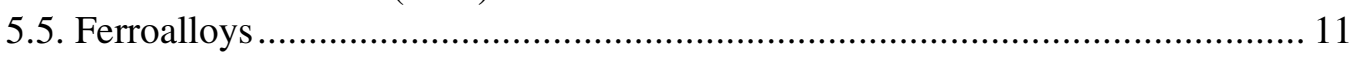

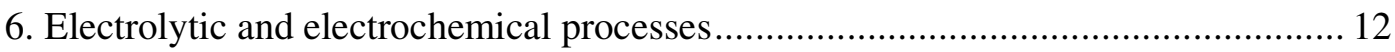

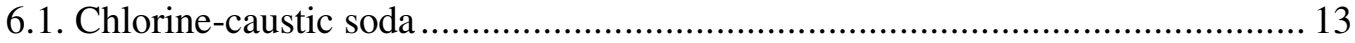

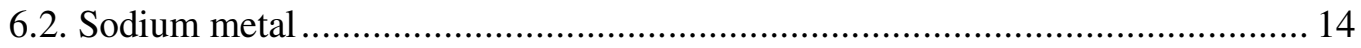

6.3. Tetra-ethyl lead (TEL) and tetra-methyl lead (TML) .................................... 15

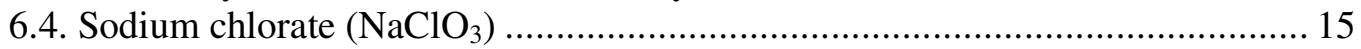

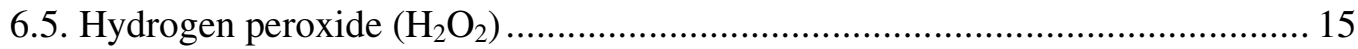

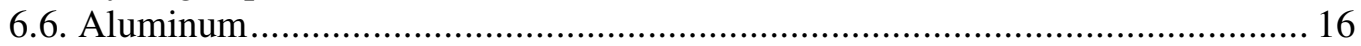

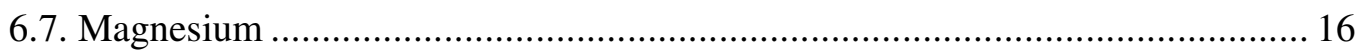

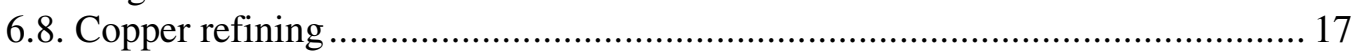

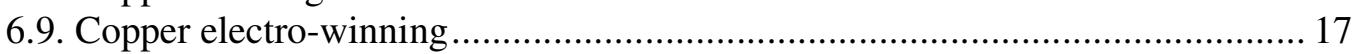

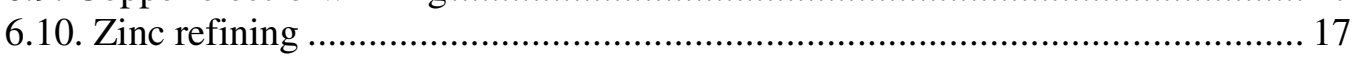

7. Electronic communications and signal processing .............................................. 18

8. DC electric motors for traction and transport................................................ 19

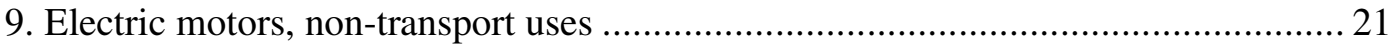

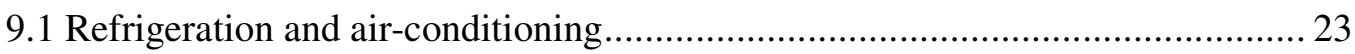

9.2 Other motor drive, unallocated.............................................................. 26

10. Summary; Secondary efficiency and opportunities for improvement ................... 27 


\section{Abstract}

This article reconstructs the history of electric power uses in the US from 1900 through 1998 from a number of different sources of data. The uses are grouped into functional categories, viz. lighting, electrolysis, high temperature heat (electric furnace applications), low temperature heat (space heating and hot water), motor drive and electronics (radio, TV and information processing). Motor drive accounts for by far the largest absolute share of consumption, while low temperature heating is by far the most rapidly increasing application. We were able to subdivide motor drive into transportation applications (very important in the early years), air-conditioning and refrigeration, and 'other', but a further breakdown has not been possible, based on available data. The article also estimates the efficiency of conversion from electric power to 'secondary work' for each application, based on historical data (where available) and estimates. All applications have become increasingly efficient, although at markedly different rates. Finally, we develop an estimate of the overall conversion efficiency of electricity to secondary work. Surprisingly, the overall efficiency has remained almost constant during the past century, even though all individual applications have become more efficient, because the least efficient application (low temperature heat) has sharply increased its share. 


\section{Acknowledgments}

The authors wish to acknowledge the invaluable critical reviews and revisions undertaken by John de Young and members of the staff of the Minerals Information team of the U.S. Geological Survey.

A draft of this paper has been accepted to Energy - The International Journal. 


\section{About the Authors}

Robert U. Ayres, Ph.D. in physics, currently Institute Scholar at IIASA, and Professor Emeritus at INSEAD. Author and co-author of 18 books and many articles and book chapters on technology, economics and environment.

Leslie W. Ayres, mathematician and computer systems, currently specializing in database construction and analysis. She has co-authored and co-edited 8 books.

Vladimir Pokovsky, Ph.D. in physics, formerly senior scientist of a research institute in Siberia, currently affiliated with the University of Malta, author of many research papers and books on technology and economic theory. 


\section{On the Efficiency of US Electricity Usage since 1900}

Robert U. Ayres, Leslie W. Ayres, Vladimir Pokrovsky

\section{Background}

In other publications it has been shown that economic growth is very strongly correlated to useful physical work [Ayres and Warr 2002; Ayres and Warr 2003; Ayres and Warr 2003]. Sources of work include human and animal muscles, water power, wind power, heat engines - all characterized as 'prime movers' -- chemical work and heat transfer systems [Ayres and Warr 2003]. Electric power is essentially pure physical work, obtained from prime movers (mostly steam or water turbines) since it can be converted to other forms of work with little or no loss. The increasing use of electricity during this century, combined with the increasing efficiency of power generation, accounts for much of the physical work produced within the US economy.

In this paper we characterize the main functional uses of electricity by the US economy since 1900. The major functional uses discussed are lighting, electrolysis, high temperature heat (from electric furnaces), low temperature heat (hot water, cooking, etc.) motor drive, and electronic devices. We also discuss certain applications of motor drive involving compressors and pumps separately. Major uses of compressors are natural gas pipelines, ammonia, methanol, ethylene and many other chemical synthesis processes, refrigeration and air conditioning. Pumps are extensively used in virtually every sector of the economy.

A database for electricity use in the US in the twentieth century has been constructed from a variety of sources. It is shown in Appendix A, along with a complete description of the sources and derivation of the data presented. A summary of electricity supply by source and major sector (residential, commercial and industry, and 'miscellaneous power and light') is given in Table A-1. The miscellaneous category is re-allocated among transport, street and highway lighting, telephone and electronics, and 'other' (which probably includes military uses not elsewhere classified). Allocations by sector and within sectors are shown in Tables $A-4 a, b$ (non-manufacturing and manufacturing), Table A-12 (residential) and Table A-13 (commercial). The uses of electric power as percentages of the total are also plotted graphically in Figure 1 and Figure 2.

We estimate the efficiency of each of those uses subsequently (see below). This data enables us to calculate an overall efficiency trend for the use of electric power in the US since 1900. However, for the sake of completeness, we briefly discuss the efficiency of electric power generation before moving on to other topics. 


\section{Generating efficiency}

The term 'efficiency' is used (and misused) in several ways in the historical literature. For purposes of what follows, we define efficiency in the so-called 'second-law' sense, as distinguished from the more familiar 'first law' usage, as spelled out in the report of an important study sponsored by the American Physical Society [APS 1975]. Very briefly, the 'first law' efficiency (normally used in engineering work) refers to the ratio of 'useful' outputs to inputs. This term is often used to describe the efficiency of a combustion process in terms of the fraction of the chemical energy in the fuel that is converted into heat available for further use, i.e. captured by a heat exchanger or - in the case of a stove or fireplace radiated into the room. Thus a reported efficiency of $80 \%$ (e.g. for a gas-fired furnace) means that only $20 \%$ of the heat generated is lost up the chimney.

As a matter of interest only, Table 1 shows a comparison of space-heating efficiencies is taken from three sources. The first column of numbers was taken from an influential book on energy sources, published in 1952 ([Ayres and Scarlott 1952], Table 12 plus data in text). The second column is taken from a report on energy efficiency published by a UN agency [UNECE 1976a]. In both cases the efficiencies given are 'first law'. The last column is taken from the APS study cited above.

Second-law efficiencies for electric heat pumps (or air-conditioning/refrigeration) must take into account the efficiency with which the electricity is generated and transmitted, which was taken to be about 0.3 in the APS study.

The APS summer study cited above defines second-law efficiency as the ratio of the least input of energy (exergy) that is theoretically possible for a given thermodynamic process, to the actual energy input required based on current technology. Second law efficiencies are significantly lower than first law efficiencies in many cases, as indicated in Table 1, although the two efficiencies are identical in the case of electric power generation. In the case of heat pumps (and refrigerators), the second law efficiency is equal to the first law efficiency times the ratio of actual 'coefficient of performance' (COP) to maximum theoretically possible COP. ${ }^{1}$ The theoretical maximum COP for a heat pump between $5^{\circ}$ and $20^{\circ} \mathrm{C}$ is around 20 . Hence, for a COP of 3 the second-law efficiency was estimated by the APS group to be $4.5 \%(0.3 * 3 / 20=0.045)$. For hot water, where the upper reservoir temperature is higher, the efficiency is also higher.

For space heating (as well as water heating and cooking) the difference between firstlaw and second-law arises from the fact that it is theoretically possible to achieve the same function by other (more efficient) means. For example, if the fuel were converted to electricity by a fuel cell with a maximum theoretical efficiency of $80 \%$ and then used to drive

1. An ideal heat pump operating between a cold reservoir at $5^{\circ} \mathrm{C}$ and $20^{\circ} \mathrm{C}$ using a Carnot cycle would have a COP of 19.5. However heat must be delivered through a heat exchanger, and the efficiency of a heat exchanger is proportional to the temperature gradient and the surface area. For a heat pump with a heat exchanger small enough to fit through the door of a house, it is necessary to deliver the heat to the exchanger at $45^{\circ} \mathrm{C}$, which cuts the COP to 6.4. Taking into account other limitations, such as compressor losses and the use of a Rankine cycle rather than a Carnot cycle, brings the practical maximum COP down to around 4, which is only $20 \%$ of the theoretical maximum [Heap 1983]. 
heat pumps of maximum theoretical efficiency $(\mathrm{COP}=20)$, the space could be heated with a tiny fraction of the energy actually used by the conventional system.

\section{Transmission efficiency}

Today transmission losses between central power plant and end user account for roughly $6 \%$ of the gross electric power generated in the US, thus transmission efficiencies are reckoned to be quite high, of the order of $94 \%$ as of 1998. According to official statistics, Transmission and distribution losses were $7.9 \%$ in 1989 and 1970, 9.5\% in 1950, 11\% in 1940, $11.9 \%$ in 1930 and $12.1 \%$ in 1917 . The latter corresponds to an average transmission efficiency of 88\%. The improvement since 1917 is largely the result of the growing use of very high voltages for long distance transmission. ${ }^{2}$

The average transmission efficiencies in earlier years may actually have been slightly lower because shorter distances were involved: there was very little long-distance transmission in the early years. As regards the future, there is still some room for improvement. Several prototype superconducting systems (cooled by liquid nitrogen) are now being tested in the US and Europe.

\section{Electric lighting}

Thomas Edison's first commercial incandescent lighting system (which included generators and local distribution) went into service in Manhattan in 1888. The electrical industry was created, originally, to supply lighting for commercial and (later) residential purposes. The first users were hotels and steamships. Residential use in central cities followed soon, however, and grew rapidly.

In the first report to stockholders of the newly created General Electric Co., (formed in 1992 by a merger of the Edison Companies with the Thomson-Houston Company) it was reported that there were 1277 central station lighting companies in the US using ThomsonHouston or Edison equipment, supplying 2,500,000 incandescent lamps and 110,000 arc lamps. At the time, a single generating unit could supply about 50 lights.

The first year for which data on residential and commercial uses of electric power were collected was 1912, when residences consumed 0.910 bkwh and commercial uses accounted for $4.076 \mathrm{bkwh}$, out of a total of $25 \mathrm{bkwh}$. (The rest was used for industrial purposes and urban or inter-urban passenger transport). Residential demand grew more rapidly after 1912, and equaled commercial usage by 1933.

The first year for which lighting usage in residences was explicitly estimated was 1915, when the Middle West Service Co. reported that $94.2 \%$ of consumption in its area was for incandescent lighting ([Schurr and Netschert 1960] Table C-34, p.623). More consistent estimates were made by the Edison Electric Institute (EEI) from 1926 until 1941. In 1926 lighting accounted for $64.7 \%$ of residential use, declining gradually to $34.3 \%$ by 1941 when

2. As a matter of interest, the first long-distance transmission system in the world was inaugurated in 1891, in

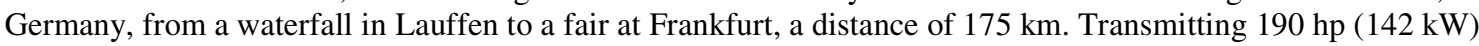
at $25,000 \mathrm{~V}$ the line achieved an efficiency of $75 \%$, or a loss rate of $33 \%$. 
the series terminated. Another series of estimates by Ebasco (a consulting organization) based on data supplied by Westinghouse Electric Co. began in 1937 (38.8\%) and continued until $1953(31.7 \%)$. This series agreed fairly closely with the EEI data during the period of overlap (1937-1941). Another series prepared by Ebasco using data from General Electric Lighting Division began in 1945 (with an estimate of 48.6\%, significantly higher than the EbascoWestinghouse estimate for that year, which was 34.8\%) and continued through 1956 (29.2\%).

The difference between Westinghouse and GE data are hard to explain. However, using these figures, Schurr \& Netschert [Schurr and Netschert 1960] have estimated residential consumption for lighting from 1912 through 1955. Lighting accounted for $30 \%$ of national electricity consumption in 1950 according to a study of the energy sector as a whole ([Ayres and Scarlott 1952] p.140).

Estimates of household consumption for lighting purposes are quite diverse, mainly because the methodology used by most authors is to start from data on the distribution of various electricity using appliances, together with average hourly consumption and survey data on the number of hours each type of appliance is in use. It is obvious that there are many uncertainties in this approach, especially if lighting is treated (as in some studies) as a residual. Very few studies have taken industrial lighting into account. A rather detailed study of electric power consumption in the industrial sector - but not including residential or commercial uses - was carried out for 1946 ([Woytinsky and Woytinsky 1953] Table 417). In that year (1946) lighting accounted for $7.7 \%$ of industrial electricity consumption $(3.8 \%$ of the national total).

Stanford Research Institute prepared a report for the Office of Science and Technology Policy of the Executive Office of the President covering energy consumption for the years 1960-1968 [SRI 1972]. For the years 1960 and 1968 SRI allocated $27.4 \%$ and $17.5 \%$ of residential electricity, respectively, to "other" unspecified uses, which included lighting ( ibid, Table 17). However residential lighting (for 1968 only) was specifically estimated to be $10.8 \%$ of residential electricity (based on data in ibid, p.10 and Table 1). This was $6.1 \%$ of residential and commercial use combined, or $3.32 \%$ of the national total. The calculation was very crude: it was based on the simple assumption that in an average household five (5) 100W incandescent bulbs burned for 4 hours each day on average (ibid, p. $62)$.

In the commercial sector SRI allocated 10\% (1960) and 34.5\% (1968) to "other", without any detailed breakdown. (The dramatic increase in "other" between the two years seems implausible and creates doubts about the validity of the rest of the numbers. See the discussion below). Without any explanation, $1.5 \%$ of total energy, or $7.32 \%$ of total national electrical energy consumption was allocated to residential and commercial lighting combined (ibid, p.7). Subtracting 3.32\% (the residential share of lighting) from $7.32 \%$ (for residential and commercial together) implies that $4 \%$ of national consumption was used for commercial lighting, which in turn used $23.8 \%$ of the national total electricity consumption. Working back, this suggests that the commercial sector allocated $16.8 \%$ of its electrical energy to lighting purposes in 1968.

The SRI data were updated, revised and considerably improved for 1973, by Ross and Williams [Ross and Williams 1975]. They concluded that residential and commercial consumption, plus unaccounted for industrial consumption, would account for about $21 \%$ of 
total electricity [Ross and Williams 1975], cited in Lovins ([Lovins 1977] Table 4.1 p.75). None of the above mentioned studies made any allowance for street lighting. Adding that item to the 1973 Ross-Williams data would bring the national total up to around $23 \%$. It is noteworthy that in their study lighting accounts for $13 \%$ of residential use and just over $60 \%$ of commercial use. By way of comparison, the General Electric Co. estimated that $24 \%$ of the total national electric power consumption was used for lighting in the year 1970 ([Summers 1971] p.353). The two estimates are fairly consistent.

We conclude that the 1968 SRI estimates of household consumption for lighting (10.8\% of household electricity consumption) and $16.8 \%$ of commercial consumption were almost certainly too low - drastically so in the latter case. To correct for this misallocation we have made an exponential interpolation between 1956 (from Ebasco) and 1973, using the figures estimated by Ross and Williams (above). This change affects the other numbers in the SRI study. The interpolations yield the following: $16.5 \%$ for lighting as a share of residential electricity use and $61.2 \%$ for lighting as a share of commercial electric power consumption. Obviously the large share of commercial electric power consumption attributed to "other" in 1968 was really for lighting. The adjustments obviously affect the distribution among other functional uses to some extent since the sum total cannot exceed $100 \%$. 
National energy consumption for 1979 was compiled by Nathaniel Guyol from Census data. Guyol also estimated that lighting consumed $11 \%$ of residential electricity and $41 \%$ of commercial electricity consumption (most of the remainder being used for air conditioning and refrigeration.) ([Ayres 1989b] Appendix A). Guyol also allowed for street lighting as a separate item, although he did not break out lighting from other uses in manufacturing. The total accounted for in his analysis came to $14.6 \%$ of the national total. A rather detailed study of the lighting sector published in 1988 concluded that lighting accounted for $22 \%(17-27 \%)$ of national electricity consumption in c.1985 [Lovins and Sardinsky 1988]. The Lovins study was the only one that explicitly allowed for uncertainty in the estimates.

Recent data from the Energy Information Agency of the US Department of Energy, explicitly distinguishes industrial lighting as well as commercial and residential lighting, In 1998, industrial light amounted to $1.65 \%$ of the national total, or $5 \%$ of industrial use of electricity, while lighting for all purposes accounted for $12.5 \%$ of the national total. The decline since the 1960s and 70s reflects some degree of saturation in the building sector. Collecting data from all sources, and adjusting where inconsistencies made it necessary, we arrived at the summary shown in Table A-15. Overall, lighting accounted for $23 \%$ of the national electricity budget in 1902 and $15.7 \%$ in 2000 . The decline occurred mainly in two periods, 1912-1917 and again 1972-1978.

The efficiency of electric lighting has increased significantly, since 1900. Incandescent lamps at the time were about $1 \%$ efficient (based on 400 lumens/watt). By 1970, the efficiency of incandescent lamps had risen to 5\% (with much of the improvement taking place between 1905 and 1910, due to the introduction of tungsten filaments). There was not much improvement after 1930. Fluorescent lamps, introduced in the 1930s, were about $8 \%$ efficient in 1940 and $20 \%$ efficient by 1970 [Summers 1971]. According to General Electric Co. (quoted by Summers), fluorescent lamps provided $70 \%$ of total illumination in 1970, while incandescent and 'high intensity' lamps split the remainder. This works out at $13 \%$ overall efficiency for that year.

However, a more detailed calculation in the late 1980s concluded that the average output of incandescent, fluorescent and high intensity lamps was 16, 66 and 48 lumens/watt, respectively, for an overall average of 44 lumens/watt or $11 \%$ average efficiency, slightly below the Summers figure cited above [Lovins and Sardinsky 1988]. However the two figures are not wildly different. So-called compact fluorescent lamps (to replace incandescent lamps) have been introduced since the 1980s, but the market penetration of these units is still small.

It is important to note that lumens are not a measure of work output, but of an intermediate service (illumination). This raises a question of consistency, which we reconsider in the concluding section. 


\section{High temperature electric heat}

There are many manufacturing processes that require high temperature heat. The most familiar is the electric arc furnace process for melting scrap iron to make steel. We discuss this process below. Other examples include (1) synthetic abrasives (such as silicon carbide, tungsten carbide, and various borides and nitrides (2) the manufacture of phosphorus metal, (3)specialized industrial ceramics (4) heat treatment of metals (5) heat forming (continuous casting, hot rolling, extrusion, wire drawing, sintering of powders, etc. Electric heat has been substituting for process steam throughout the chemical industry, in particular, because of the reduced capital costs, due to elimination of piping systems. There is evidence that the electric fraction of total energy consumption in the chemical industry also increased significantly, from 29.6\% 1974 to $34.7 \%$ in 1981 [Burwell and Reister 1985]. In this case, compressors (e.g. for ammonia synthesis and cryogenic units) and pumps accounted for some of the increase, but electric heating applications continue to play a significant role.

Very high temperatures are needed to melt certain metals, including chromium, nickel, cobalt, niobium, molybdenum, stainless steel and the so-called super-alloys (used in jet engines.) Lower temperature processes in metallurgy are increasingly important, however, for rolling, wired drawing, and heat treatment. There is evidence of very rapid growth in the number of electrical heat treating units in US metallurgical and engineering industries after 1960. There are two types: conventional resistance heaters [Miller 1976] and coreless induction heaters [Barbier 1976]. Both types were increasing rapidly in use, especially the newer induction type. For instance, in the year 1958 the total number of induction heaters installed in the US was roughly 30. By 1974 the total number of units had increased to around 1100, of which about 580 were used for (scrap) metal melting, including continuous casting machines, 410 for heat treating of metals, while the remainder were used for metal forming applications, such as hot rolling, wire drawing. extrusion and sintering of metal powders [Barbier 1976].

In 1946, according to the Census of Manufactures electric heat accounted for $13.9 \%$ of manufacturing consumption of electricity or about 16.8 bkwh [Woytinsky and Woytinsky 1953]. The electric steel share in that year was only $2.5 \mathrm{bkwh}$, according to the above table. The allocation of electricity for heat, among industrial sectors, was as follows: chemical industry $42.2 \%$ (6.0 bkwh), the iron and steel industry, 25.4\% (3.6 bkwh, of which electric steel took $2.5 \mathrm{bkwh}$ and ferroalloys the rest), non-ferrous metals $12 \%$ (1.72 bkwh), machinery (0.69 bkwh), electrical machinery 6.3\% (0.91 bkwh) and all others (4.9 bkwh) [Woytinsky and Woytinsky 1953]. This was the only year for which we found such a breakdown, prior to 1991.

At first sight there seems to be an inconsistency between the 1946 Census data, (Woytinsky, cited above, and the SRI study [SRI 1972] which only allocated $4.9 \%$ of manufacturing electricity use to heat in 1960, and 5.9\% in 1968. The 1973 update by Ross and Williams [Ross and Williams 1975] allocated 7.8\% to heat, which seems reasonably consistent with the SRI figures for 1960 and 1968. However, the percentage decline from 1946 to 1960 corresponds to an absolute decline in "other" high temperature heat uses mainly chemicals and non-ferrous scrap melting - from 11.1 bkwh in 1946 to only 5 bkwh in 1960. It is barely possible but unlikely that such a decline occurred during that period, in view of actual increases in the demand for some energy intensive chemicals, especially acetylene, carbon disulfide and phosphorus metal by the furnace route, that were subsequently phased out. (See below). Acetylene production and phosphorus production by 
the furnace process both peaked in 1966 and remained high for several years. Carbon disulfide production seems to have peaked in 1972. For this reason we think that "other" high temperature heat uses must have increased in absolute terms from 1946 to at least 1966, at least, although it might have declined subsequently. In effect, we are forced to disregard the SRI numbers (and those of Ross and Williams, which supposedly updated them) for high temperature electric heating.

In 1998 electric process heating in the manufacturing sector accounted for 106.3 bkwh, or $10.8 \%$ of the total used in that sector. The heating fraction had risen from $8.7 \%$ in 1991, which was the first year since 1946 for which we have government data. The 1998 breakdown was as follows: chemicals (SIC 325) consumed $5.11 \mathrm{bkwh}$, while plastic and rubber products (SIC 326) took $8.47 \mathrm{bkwh}$ and non-metallic mineral products (SIC 327) consumed $9.29 \mathrm{bkwh}$, of which half was for glass and glass products. (Evidently electric furnaces have been replacing combustion furnaces for glass, and ceramics. There was no indication of this use in the 1946 survey. Unfortunately we have no data on the quantities involved)

Nearly half of the total was used in the primary metals sector SIC 331, of which 22.1 bkwh was for iron and steel mills (mostly using the electric arc furnace process), 2.9 bkwh was used for ferroalloy production (now SIC 331112), 8.4 bkwh was used in the primary aluminum sector, 9.1 bkwh was used by foundries of all kinds. Fabricated metal products (SIC 332) consumed $7.8 \mathrm{bkwh}$; machinery (SIC 333) took $2.55 \mathrm{bkwh}$; computers and electronic products (SIC 334) consumed $5.44 \mathrm{bkwh}$; and the transportation equipment industry (SIC 336) consumed $5.46 \mathrm{bkwh}$. Metallurgical uses were mostly for scrap recovery, with a smaller fraction for heat treatment.

Available data on the uses of electricity for high temperature process heat are summarized in Table A-7. A few specific electro-thermal processes are worth discussing at greater length, below.

\subsection{Acetylene from calcium carbide}

Acetylene $\left(\mathrm{C}_{2} \mathrm{H}_{2}\right)$ was produced and consumed in large quantities at the end of the $19^{\text {th }}$ century and the beginning of the $20^{\text {th }}$, mainly for lighting; more recently it has been primarily used for welding. It was produced on site from calcium carbide, made in electric furnaces by a process invented by T. L. Willson and commercialized in 1892. The process involves heating coke and lime together at a very high temperature in an electric arc furnace. Acetylene quickly found a market for domestic lighting in gas lamps. In 1899 there were 8000 acetylene plants in Germany alone, providing fuel for a million gas jets [Burke 1978] p.209. In fact, the German organic chemical industry was acetylene based until long after WW II. For instance, butadiene (a component of several types of synthetic rubber) was acetylene based.

In 1899 Union Carbide got control of the carbide business in the US and centralized its production at Niagara Falls, where it built a plant with a capacity of 8000 tons (7200 metric tons) per month, or about 86,000 metric tons of carbide per annum, consuming 300 million kWh or 0.3 bkwh per year.[Clark 1949], Chapter XIX. Demand increased rapidly and Union Carbide soon built another plant near a hydroelectric facility at Sault St. 
Marie, between Michigan and Canada, where it, and United Electrical Co. contracted for another $30,000 \mathrm{~kW}$, or $0.3 \mathrm{bkwh}$ per annum. We can assume that electric power consumption in 1902 was close to $0.6 \mathrm{bkwh}$, just for calcium carbide (acetylene) manufacture.

However the domestic use of acetylene for gas lighting in cities seems to have declined almost as fast as it had risen thanks to the success of the Welsbach mantle and the incandescent light .It was used thereafter mainly in rural areas and as a chemical feedstock for the manufacture of acetic acid, acetone, acetaldehyde, acrylonitrile, acrylates, vinyl acetate, vinyl chloride, tri- and perchlorethylenes. Most of these feedstock uses were displaced by ethylene or propylene during the decades from 1950 to 1970 (see Table 2). Nevertheless, production increased continuously until 1965, when it peaked [Burwell and Reister 1985].

At first, acetylene production was produced exclusively by the calcium carbide process. An alternative, the Huels plasma arc process was commercialized in 1940 (in Germany). A variant was adapted after the war by Dupont in the US. It uses hydrocarbon feedstock (possibly butane or propane) [Lowenheim and Moran 1975] p.32. There are several other commercial processes for producing acetylene from hydrocarbons, notably Wulff (pyrolysis from paraffins) and Sachsse.(partial oxidation from natural gas) These processes are less electricity intensive than the carbide and plasmarc processes.

Electricity consumption by the carbide process in the late $1890 \mathrm{~s}$ was $2.46 \mathrm{kWh} / \mathrm{lb}$ or $5.45 \mathrm{kWh} / \mathrm{kg}$ of carbide [Lewes 1898]. Power consumption for this process (as of the 1950s) was $3.2 \mathrm{kWh}$ per $\mathrm{kg}$ of $(80 \%)$ carbide, which is a reduction of $25 \%$ from the early years. A kilogram of carbide yields, on reacting with water, $0.4 \mathrm{~kg}$ of acetylene [Lowenheim and Moran 1975] "Acetylene". This works out at about $10 \mathrm{kWh} / \mathrm{kg}$ of acetylene. The plasmarc process also consumes $12.3 \mathrm{kWh} / \mathrm{kg}$ of acetylene. (Other processes, such as the Wulff and Sachsse processes, have cut this requirement drastically to $1.2 \mathrm{kWh} / \mathrm{kg}$ of acetylene.) However the carbide process is still significant because, unlike acetylene itself, calcium carbide is easy and safe to transport. A useful source of recent technology data is [Barbier et al 1976].

Carbide production in 1970 accounted for less than half of total acetylene output (195,000 metric tons). This implies a carbide output of about 487,500 metric tons in that year and about 1.5 bkwh of electric power. This was probably no more than $80 \%$ of peak capacity, since acetylene demand was already falling, and the newest plants were based on newer processes. Calcium carbide production in 1972 was 446,000 metric tons [USCensusMfg 1972]. Acetylene production from carbide fell to 125,000 metric tons $(375,000$ tons of carbide) in 1976 (International Trade Commission).It seems likely, therefore, that electric power consumption for the carbide industry peaked at a little above $1.5 \mathrm{bkwh}$ in 1965-66. It has declined gradually since then.

\subsection{Phosphoric acid by the furnace process.}

Phosphorus metal was produced by the electric furnace process, for conversion to phosphoric acid after1920. The electric furnace process, commercialized in 1920, consisted of reacting silica $\left(\mathrm{SiO}_{2}\right)$ with phosphate rock $\left(\mathrm{Ca}_{3}\left(\mathrm{PO}_{4}\right)_{2}\right.$ and coke. It required $4.5 \mathrm{kWh} / \mathrm{kg}$ of $(100 \%$ phosphoric acid [Lowenheim and Moran 1975] p.629. Phosphorus by electrothermal reduction consumed 7.2-9.9 $\mathrm{kWh} / \mathrm{kg}$. (Metallic phosphorus was also produced for a time, in the 1930 s, by a blast furnace process.). 
The furnace process consumed $13.4 \mathrm{kWh} / \mathrm{kg}$ in 1954 , or $5.85 \mathrm{kWh} / \mathrm{kg}$ of $100 \%$ phosphoric acid $\left(\mathrm{P}_{2} \mathrm{O}_{5}\right)$. Since the electric furnace process for phosphorus is very similar to the carbide process discussed above, one can probably assume that the efficiency improvement since 1899 was comparable. The so-called furnace process accounted for about $45 \%$ of total phosphoric acid in the period 1949-1954 during which total output doubled, from about 0.5 million metric tons to 1 million metric tons $\left(\mathrm{P}_{2} \mathrm{O}_{5}\right.$ basis). Furnace production in 1966 was 1.52 million metric tons; falling to 1.415 million metric tons in $1967\left(\mathrm{P}_{2} \mathrm{O}_{5}\right.$ basis) [USBuMines 1967p]. Evidently phosphoric acid production in the 1946 consumed close to $1.5 \mathrm{bkwh}$, increasing to $2.5 \mathrm{bkwh}$ in 1954 and perhaps $4.5 \mathrm{bkwh}$ in 1966 (peak year). During the postwar years acetylene and phosphorus must have accounted for most of the "other" uses of electric power for high temperature heat.

Furnace production declined slowly after 1968, as phosphates were phased out of detergents for environmental reasons. We have no production data after 1973, when furnace production was about 800,000 metric tons [Lowenheim and Moran 1975]. Phosphorus metal production in 1972 was 491,000 metric tons [USCensusMfg 1972]. The so-called 'wet process' increased its share from 55\% to about $87 \%$ (in 1973). It has replaced the furnace process completely for fertilizer super-phosphates. However the furnace process is still used to produce other phosphorus chemicals, e.g., for water softeners.

\subsection{Carbon disulfide $\left(\mathrm{CS}_{2}\right)$}

This chemical was produced by direct reaction of charcoal with sulfur, at $800^{\circ}-1000^{\circ} \mathrm{C}$. in an electric furnace. Electricity requirement was $1.65 \mathrm{kWh} / \mathrm{kg}$ [Lowenheim and Moran 1975]. This process was replaced in the 1960 s by a catalytic process in which sulfur reacts with natural gas at a slightly lower temperature $675^{\circ} \mathrm{C}$ in a furnace heated by combustion. From 1954 to 1974 production rose erratically from 220,000 to 350,000 metric tons. We assume that additional output after 1954 was based on the catalytic process, and that the electrolytic process was completely phased out by 1974 . Thus electricity consumption would have been about 0.36 bkwh in 1954, declining thereafter (more or less) monotonically until 1974. (In reality, of course, the decline would have been stepwise, as plants were closed. Carbon disulfide was used primarily in the production of rayon and cellophane. During the 1960s about $25 \%$ of the output was used to manufacture carbon tetrachloride. This process was later replaced by direct chlorination of natural gas.

\subsection{Electric arc furnace (EAF) steel}

The most important metallurgical use of electric heat is in the steel industry. There are two branches. The older one is for melting and refining ferroalloys, such as ferro-manganese and ferro-chrome, and for producing stainless steel. A more recent, and even bigger use is for remelting and recycling steel scrap. All of these uses (plus the electrolytic uses) have been lumped together as "Primary metals" in Historical Statistics. We propose to disaggregate further, with the help of recent work by Considine et al [Considine et al 2000; Considine et al 2001].

Data on total electric power consumption for steel-making is available for a number of years before the 1990s e.g. [USBuMines 1988]. However the data are not broken down to distinguish EAF consumption from other uses of electricity, such as in rolling mills. In the early years of the century non-furnace uses were relatively minor, and most electric power consumed by the steel industry was for electric furnaces producing ferroalloys, stainless steel 
and other alloy steels (such as tool steel). It seems reasonable to assume that $80 \%$ of the 1917 electricity consumption by the steel industry $(5.15 \mathrm{bkwh})$ was for electric furnaces. This would imply that consumption per $\mathrm{kg}$ was about $1.55 \mathrm{kWh}$. Thirty years later (1947) reported electricity consumption for 3.43 million metric tons of electric steel was $3.63 \mathrm{bkwh}$, or 1.06 $\mathrm{kWh} / \mathrm{kg}$. Since alloy and stainless steel were the main products of EAF furnaces prior to 1960, whereas carbon steel became the dominant product after 1970, it can be seen that the overall requirements probably dropped from $1.55 \mathrm{kWh} / \mathrm{kg}$ (est.) in 1917 to $1.06 \mathrm{kWh} / \mathrm{kg}$ in 1947, and perhaps to $0.8 \mathrm{kWh} / \mathrm{kg}$ in 1960.

The standard source book on steel manufacturing technology [USS 1971] reported measured data from one furnace melting scrap, averaging over a large number of batches, which worked out at 400-425 kWh/ton for melting plus $122 \mathrm{kWh} /$ ton for refining. This converts to $522-547 \mathrm{kWh} /$ ton or $0.587-0.600 \mathrm{kWh} / \mathrm{kg}$ (ibid, p.572). The date was not given, but it can be presumed to be mid- or late 1960s.

Calculating from aggregate 1968 data yields an estimate of $0.526 \mathrm{kWh} /$ ton of average electric steel [Vaughan et al 1976]. In a study for EPA, Gordian Associates provided data from which one can calculate an intensity of $0.484 \mathrm{kWh} / \mathrm{kg}$ for 1971 [Gordian 1975]. Finally, in a study for the Ford Foundation Energy Policy Project, explicit estimates are provided for carbon steel and alloy steel (mostly stainless steel) separately, namely $500 \mathrm{kWh} / \mathrm{ton}$ for carbon steel and $700-720 \mathrm{kWh} /$ ton for alloy steel, or $0.555 \mathrm{kWh} / \mathrm{kg}$ and $0.772-798 \mathrm{kWh} / \mathrm{kg}$, respectively.

More recent data compiled for a recent study of technology adoption in the steel industry, using a similar methodology, has been provided for the years 1974, 1978 and 1988 through 1998 inclusive [Considine et al 2001]. The reduction in energy intensity for EAF steel has continued, more or less smoothly, to $0.415 \mathrm{kWh} / \mathrm{kg}$ in 1998 . Table A-5 summarizes the available data.

\subsection{Ferroalloys}

We have been unable to obtain data on the consumption of each individual ferroalloy since the beginning of the century. From US Bureau of Mines data since 1908 we were able to produce a time series for a group of 8 ferroalloys, which we lumped together. Electric power consumption for this group as a whole (but not for the individual alloys) was available for a few years. From Historical Statistics (1900-1970) we were able to derive a different series, based on total inputs (ores). The two series differ in coverage, especially in that the more recent series includes ferro-silicon (extremely energy intensive) while the earlier one does not. A further difficulty arises from the fact that the earlier series includes alloys produced in a blast furnace (especially ferro-manganese and ferro-chrome) as well as alloys made in electric furnaces, whereas the Bureau of Mines data distinguishes the two. The SIC 3313 (electro-metallurgical products) seems to coincide with the Bureau of Mines data. For this reason we have constructed a single series for ferroalloy production in electric furnaces by combining the sources, using proportionality coefficients and interpolations or extrapolations where necessary to fill gaps. Unfortunately, the time series does not show a clear trend, due to wide fluctuations from year to year in the composition of the mix. In different years different ferroalloys were produced in extremely variable quantities. Table A-6 summarizes the available data on ferroalloys. 
In interpreting our estimates, it is also helpful to bear in mind that some alloys are much more energy intensive than others, ranging from ferro-manganese $(2.3-2.9 \mathrm{kWh} / \mathrm{kg}$ ), ferro-chromium $(3.6-4.8 \mathrm{kWh} / \mathrm{kg})$, up to ferro-silicon $(11-12 \mathrm{kWh} / \mathrm{kg})$.

\section{Electrolytic and electrochemical processes}

As in the case of electric furnaces, electrolytic process are utilized in a number of manufacturing sectors apart from the obvious examples (chlorine, copper, aluminum) discussed in detail below. The value of electrolytic chemicals produced in the US as a fraction of all chemicals increased from $3 \%$ in 1899 to $15 \%$ by 1920 , mainly due to the availability of low cost electric power [Clark 1949]. Subsequently other processes, notably catalytic processes based on natural gas, replaced some of the electrochemical processes that had been important earlier.

The allocation among manufacturing sectors is available for the year 1946 [Woytinsky and Woytinsky 1953]. In that year total industrial use was $17.6 \mathrm{bkwh}$, divided among sectors as follows: non-ferrous metals, aluminum and copper (7.25 bkwh), chemicals, mainly chlor-alkali (4.72 bkwh), with the rest spread out widely, e.g. $2.2 \%$ of pulp and paper (for on-site manufacturing of hydrogen peroxide for bleaching), $1.9 \%$ of electrical machinery (for electroplating), and even $1.6 \%$ of electric power consumption in the food industry (for unknown purposes).

According to the 1998 Manufacturers Energy Consumption (MEC) survey [MEC 1998] manufacturing used $103.6 \mathrm{bkwh}$ for electrolytic processes, of which $56.5 \mathrm{bkwh}$ was used in primary metals (49.9 bkwh for aluminum reduction alone), and $41.3 \mathrm{bkwh}$ was used in the chemical sector (of which $17.0 \mathrm{bkwh}$ was attributed directly to chlorine and caustic soda production, 15.7 bkwh was for 'other basic organic chemicals', SIC 325199, the rest being distributed across other chemical sub-sectors.) This allocation is inconsistent with known electric power requirements for the chlor-alkali electrolysis process, which requires about $3 \mathrm{kWh}$ per 'electrochemical unit', consisting of $1 \mathrm{~kg}$ chlorine plus $1.13 \mathrm{~kg}$ of caustic soda $(\mathrm{NaOH})$. (Evidently the chlor-alkali sector alone should be consuming about twice as much electric power as was allocated to it by the survey, the remainder probably having been misallocated to 'other organic chemicals, and plastics. A more detailed explanation is given below.) Electroplating of fabricated metal products SIC 332 seems to have accounted for 2.26 bkwh, while 1.2 bkwh was for computers and electronic products SIC 334, including 0.55 bkwh for semiconductor manufacturing SIC 334413.

In the chemical industry electrolytic processes have included the manufacture of sodium, caustic soda, soda ash, chlorine and caustic soda, sodium chlorate, sodium metal, adiponitrile (Monsanto process), and some others. Soda ash was manufactured by the electrolytic process in the early 1880s, although the non-electrolytic ammonia-soda (Solvay) process soon captured that market. Ammonia was briefly made from electrolytic hydrogen $(11.7 \mathrm{kWh} / \mathrm{kg})$; in $194815 \%$ US of ammonia production was actually based on hydrogen obtained by electrolysis of water, while only $10 \%$ was derived from natural gas (the remainder being from water gas or coke oven gas). Just 7 years later, in 1955, the electrolytic hydrogen share (of a much larger total) was down to $4.5 \%$ while natural gas accounted for $81 \%$ [Shreve 1956].

Other important chemicals and metals now or formerly produced by electrothermal or electrochemical processes include calcium cyanamide $(2.5 \mathrm{kWh} / \mathrm{kg})$, the first synthetic 
nitrogen chemical. Melamine, a plastic (used for telephones), was originally manufactured from calcium cyanamide by electrolysis, but this process was obsolete by 1960 . The above intensity figures all refer to c. 1955[Shreve 1956]. Assuming improvements at rates similar to the other processes for which we have data, it is reasonable to assume that consumption per unit output is down by $30 \%-50 \%$ in most cases.

Metallurgical applications of electrolysis are mainly for aluminum reduction from alumina, copper refining from blister copper, electrowinning of copper-lead-zinc from leachpiles, zinc refining, magnesium, electroplating (e.g. chromium) and recovery of metals from process wastewater. By far the biggest use is for aluminum. Table A-11 summarizes the data we have on electrochemical uses of electricity. A few important electrolytic processes include the following:

\subsection{Chlorine-caustic soda}

Pure electrolytic chlorine production began in the US (1892) in Rumford Falls, Maine, using an electrolytic 'bell-jar' cell developed by the Electro-Chemical Company ([USEPA 1971] p.5). S. D. Warren, Olin and Dow followed shortly. Roberts Chemical Co. began producing electrolytic chlorine in 1901. Pennsylvania Salt Co (Pennsalt) began in 1903, followed by Developing and Funding Company (1905). Gaseous chlorine was first liquefied by the Niagara Alkali Company in 1909, and this made shipping so much easier that demand soared (especially for water treatment).

By 1910 there were 11 plants in the US with an installed aggregate capacity of 200 tons per day (roughly 70,000 metric tons/yr.). By 1920 total capacity had increased to 600 metric tons/day, or 210,000 metric tons p.a. [ibid]. The largest chlorine plant in production in 1928 (at Charleston S.C.) had a capacity of 100 tons/day, or 35,000 metric tons/year. The industry grew rapidly throughout the 1930s, despite the depression. By 1940, capacity was up to 2000 metric tons/day and by the end of 1969 it was 28,000 metric tons/day. Growth was so rapid that productive capacity was fully utilized during most of the time since 1910 .

The technology in use before 1945 was almost exclusively the so-called diaphragm cell; there is no significant difference in this technology and the more recent membrane cells with regard to energy consumption. An alternative, the mercury cell, made rapid inroads after World War II because the chlorine was of higher purity. This technology uses at least $25 \%$ more electricity per ton than the others. By 1970 about $26 \%$ of US production utilized the mercury cell, but half of the new plants under construction at the time were based on this technology [USEPA 1971]. However, an industrial accident in Japan called attention to the dangers of mercury emissions in the environment, and the percentage of chlorine produced by means of the mercury cell has dropped from a peak of around 30\% in the mid 1970s to around $15 \%$ today. In 1972, mercury cells accounted for $24.2 \%$ of US production; this was down to $16 \%$ in 2000 [SRI 2000]. Diaphragm cells account for $62 \%$ of current output, membrane cells account for $18 \%$ and other non-electrolytic processes $4 \%$ (USGS for 2000 gives $14 \%$ for mercury cells, $86 \%$ for other).However the mercury cell still accounts for about $65 \%$ of European output.

The first year for which we have found data on electricity consumption for chlorine production However, an industrial accident in Japan called attention to the dangers of mercury emissions in the environment, and the percentage of chlorine produced by means of the mercury cell has dropped from a peak of around 30\% in the mid 1970 s to around $15 \%$ 
today. is 1916 when diaphragm cells consumed between 3.4 and $5.3 \mathrm{kWh} / \mathrm{kg}$ and mercury cells consumed just under $4 \mathrm{kWh} / \mathrm{kg}$ according to one source [Wehle 1974] Table 10-4; 1925. In 1925 unspecified electrolytic cells consumed around $4 \mathrm{kWh} / \mathrm{kg}$ of chlorine [Partington 1925; Wehle 1974]. In 1947 electricity consumption per electrochemical unit, via the diaphragm cell, was down to $3 \mathrm{kWh}$ and by 1971 it was $2.8 \mathrm{kWh} / \mathrm{unit}$ (average), including ancillary requirements [Wehle, op. cit]. Another source for the mid-1970s was $2.84 \mathrm{kWh} / \mathrm{kg}$ of chlorine [Wehle 1974; Vlahakis and Ouellette 1976]. As of 1978, the electrolytic requirements alone, excluding ancillary needs, for diaphragm cells were $2.92 \mathrm{kWh} / \mathrm{kg}$ of chlorine. For the mercury cell, electrolytic consumption remained at $3.5 \mathrm{kWh} / \mathrm{kg}$ [Hall et al 1975]. By 1988 mercury cells consumed about $3.575 \mathrm{kWh} / \mathrm{kg}$, including non-electrolytic requirements, while the diaphragm cell used only $2.81 \mathrm{kWh} / \mathrm{kg}$ [SRI 1989a].

Based on experience with the Hall-Heroult process (discussed later) it seems likely that the first electrolytic cells in the 1890s were considerably less efficient than the cells in use in 1925. We guess that a figure of around $7 \mathrm{kWh}$ per electrochemical unit might have been applicable in 1900, and $6 \mathrm{kWh} / \mathrm{kg}$ in 1910. The production quantities at the time were so small that the uncertainty is unimportant. Table A-8 summarizes the available data on electrolytic chlor-alkali production.

An interesting anomaly is worth reporting. It is common to the Census of Manufactures and the data published by the Energy Information Agency (EIA). The electric energy allocated to 'electro-chemical processes' in the chlor-alkali sector (SIC 2812) is much lower than it should be, based on actual chlorine production data and electrolytic cell efficiency data., whereas a disproportionately large amount is allocated to other sectors, notably organic chemicals (SIC 2869). Dividing electricity consumption by chlorine production leads to an imputed intensity of $1.494 \mathrm{kWh} / \mathrm{kg}$ in $1991,1.394 \mathrm{kWh} / \mathrm{kg}$ in 1994 and $1.458 \mathrm{kWh} / \mathrm{kg}$ in 1998 . Part of the explanation seems to be that only about $71 \%$ of the chlorine is actually produced within the SIC sector 2812 (Robert Adler, EIA, personal communication, December 2002). However, adjusting for this would only increase the imputed intensity to $2.0-2.1 \mathrm{kWh} / \mathrm{kg}$ as compared to an actual average of around 2.9 or so. The only plausible explanation is that the chlorine-producing establishments not belonging to SIC 2812 responding to EIA and Census questionnaires have seriously mis-allocated their electricity requirements among their products, possibly in proportion to output value. (If chlorine is produced in integrated facilities that also produce ethylene dichloride or vinyl chloride, for instance, this explanation would make sense. At any rate, we have decided to use our numbers in this case, rather than the official ones.

\subsection{Sodium metal}

Sodium metal was and is still made by electrolysis of salt, by a process similar to that used to produce chlorine. Electricity requirements are about $16.5 \mathrm{kWh} / \mathrm{kg}$. Production was about 115,000 metric tons in 1954, dropping to a low point of 100,000 metric tons between 1958 and 1961, then rising sharply to nearly 169,000 metric tons in 1973 [Lowenheim and Moran 1975]. About $80 \%$ of the output as of 1974 was used for tetraethyl lead (TEL) and tetramethyl lead (TML) production. The classical process for manufacturing TEL began with a lead-sodium alloy. In the mid-1960s, when TEL production was around 200,000 metric tons, around 80,000 metric tons of sodium metal was consumed in the process. This sodium was produced electrolytically. Production of TEL and TML have since been phased out. The only other significant use of sodium was in titanium production, which may have increased but remains very small. We have no recent data, however. 


\subsection{Tetra-ethyl lead (TEL) and tetra-methyl lead (TML)}

These were important gasoline additives, beginning around 1930. Production rose to a peak of 252,000 metric tons in 1970, after which it was phased out gradually [Minerals Yearbooks, various years]. At least one producer (Nalco) used an electrolytic process from 1964 on, mainly for tetramethyl lead [Vlahakis and Ouellette 1976]. (This was distinct from the process to produce sodium metal, discussed above.) However Nalco's share probably never exceeded $10 \%$ of the total, and we have no other data on production levels or electric power requirements.

\subsection{Sodium chlorate $\left(\mathrm{NaClO}_{3}\right)$}

Sodium chlorate is another important chemical (mainly used for bleaching in the paper industry) that is also produced by electrolysis of sodium chloride. Production in 1954 was 37,000 metric tons, increasing to 175,000 metric tons/yr during 1972-74 [Lowenheim and Moran 1975]. Electricity consumption at that time was $5.6 \mathrm{kWh} / \mathrm{kg}$ and has remained relative constant since then $(5.8 \mathrm{kWh}$ c 1987 and $5.4 \mathrm{kWh}$ c. 1995). Output rose slowly, to 234,000 metric tons in $1985,296,000$ metric tons in 1990, but surged to much higher levels, 488,000 metric tons in 1993 and 843,000 metric tons in 2000 (C\&EN 1997). Consumption by the paper industry alone was estimated at 200,000 metric tons in 1988, rising very rapidly to 828,000 metric tons in 1993 [MEB 1995]. Obviously there is a discrepancy for 1993, which we cannot explain. Available data are summarized in Table A-8.

\subsection{Hydrogen peroxide $\left(\mathrm{H}_{2} \mathrm{O}_{2}\right)$}

This chemical came into general use after the production technology was refined during World War II, especially for torpedoes. There are still significant military-space uses, e.g. as an oxidant for hydroxylamine as a rocket propellant It first it was produced mainly by electrolysis of an ammonium bisulfate solution containing the persulfate $\left(\mathrm{S}_{2} \mathrm{O}_{8}{ }^{2-}\right)$ ion, until two newer non-electrolytic processes were introduced in the 1960s. Electricity requirements by electrolysis were $7.1 \mathrm{kWh} / \mathrm{kg}\left(70 \% \mathrm{H}_{2} \mathrm{O}_{2}\right)$ [Lowenheim and Moran 1975].

Production in 1954 was 18,000 metric tons (100\% basis), rising almost monotonically to 50,000 metric tons in 1965, and 70,000 metric tons in 1973. We assume that new capacity after 1965 was non-electrolytic, whence peak electricity consumption for this purpose was probably about 0.3 bkwh (in 1965), falling monotonically to zero by 1974 . Subsequent production has been entirely non-electrolytic. See Table A-8. 


\subsection{Aluminum}

Pittsburgh Reduction Co. (later Aluminum Company of America - ALCOA) began operations near Niagara Falls, N.Y. in 1895. A second aluminum company soon appeared on the scene. US production in 1900 was 3000 metric tons, growing to 16,000 metric tons in $1909,73,000$ metric tons in 1917, 95,000 metric tons in 1920 and after a postwar slump up 170,000 metric tons in 1929. There was a sharp drop in demand during the early 1930s, but demand began rising again in 1936. By 1941 it had reached 389,000 metric tons. Domestic demand outpaced domestic production capacity by a considerable margin, the difference being supplied from Canadian production. There was an enormous increase in demand during World War II (for aircraft), reaching 1.243 million metric tons in 1943, followed by another slump until the Korean War pushed up demand again. Since then demand has continued to rise. Electricity requirements in $\mathrm{kWh} / \mathrm{kg}$ are shown as follows, according to several sources: [Schurr and Netschert 1960; Altenpohl 1982; Atkins et al 1991]. As a matter of interest, the theoretic limit for aluminum is said to be $5.18 \mathrm{kWh} / \mathrm{kg}$. Thus the efficiency of the current Hall-Heroult process is $40 \%$. The current process represents a factor of three improvement over 1900, whence we can assume that the efficiency in that year was about $13 \%$.

Thus total electric power consumption for North American aluminum production in 1900 would have been 90 million $\mathrm{kWh}$, rising to 0.48 billion $\mathrm{kWh}$ (bkwh) in 1909, $2.1 \mathrm{bkwh}$ in 1917, 2.85 bkwh in 1920 and about 4.1 bkwh in 1929. However quite a bit of domestic aluminum consumption came from Canada (where the hydropower was very cheap) and domestic power consumption for aluminum smelting in the US in 1920 was only 1.035 bkwh, and $2.804 \mathrm{bkwh}$ in 1929. The maximum wartime power consumption in the US for aluminum for a single year was $18.87 \mathrm{bkwh}$ in 1943 US domestic production was 830,000 metric tons (consumption in that year was 1.24 million metric tons, thanks to imports from Canada.) Electric power consumption by the US aluminum industry was 10.4 bkwh in 1947, 26.3 bkwh in 1954, 36.3 bkwh in 1962 and 53.6 bkwh in 1967 [Garvey and Gelb 1974]. In 1990 the electric power consumption for electrolytic smelting alone was around $42 \mathrm{bkwh}$. Table A10 summarizes the available data on aluminum refining.

Prices dropped faster than energy consumption, due to other improvements and economies of scale. From 1835 when commercial production began, to 1880 , the price was about \$100/lb. In 1886, it dropped to $\$ 8$ per lb. By 1893 it was down to $\$ 2 / \mathrm{lb}$. In 1943-47 the average price was $\$ 0.15 / \mathrm{lb}$, rising in 1954 to $\$ 0.20 / \mathrm{lb}$ [Altenpohl 1982]. Needless to repeat, demand increased enormously, especially due to new applications - first in the aircraft industry and later in construction.

\subsection{Magnesium}

Magnesium production via the Dow process added 3.67 bkwh in 1943 and 3.14 bkwh in 1944, but dropped back sharply until another increase during the Korean War. Since then, it has been negligible. 


\subsection{Copper refining}

The first electrolytic refinery in the US was located at Laurel Hill, N.Y. (It was located on a creek that separated Queens and Brooklyn in what is now New York City). It was built in 1892. The original plant converted blister copper from other sources electrolytically into pure anode copper for wire and pipe. Later this plant was expanded and three other refineries were built in the New York harbor area, which became the copper refining center of the world, and remained so until after World War II.

Blister copper from smelters is not pure enough for electrical applications, which increasingly dominate the uses of copper. The final stage of purification (up to $99.99 \%$ is electrolytic. We do not have electric power consumption data for the first copper refineries, but the efficiency of the process has probably increased roughly in line with the efficiency of the aluminum reduction process, since the cells are similar. According to one source, electric power consumption for electro-refining was about $0.27 \mathrm{kWh} / \mathrm{kg}$ in 1975 [Gaines 1980]. Other sources for the same period (1973-74) ranged from $0.22 \mathrm{kWh} / \mathrm{kg}$ to $0.31 \mathrm{kWh} / \mathrm{kg}$ [Hall et al 1975]. More recent data from Germany gives $0,47 \mathrm{kWh} / \mathrm{kg}$ for electrolytic refining [FfE 1999]. It is difficult to account for the discrepancy unless German data reflects significant quantities of electrowon cathode copper as an input (see below).

\subsection{Copper electro-winning}

In recent decades the solvent extraction-electro-winning (SX-EW) process has become very important. The first stage is acid leaching of (low grade) oxide ores, followed by electrolytic reduction. The product is known as cathode copper. It is normally utilized as such if the purity is high enough (greater than $99.5 \%$ ), though it may be subsequently refined further for electrical uses by the standard electrolytic process yielding anode copper. Thus the output of so-called electrolytic refined copper includes both blister copper from ore, recovered scrap and cathode copper from the SX-EW process, but the electricity requirements are additive. In 1977 the SX-EW process accounted for $8 \%$ of US primary copper production, but by now (2002) the figure is more like $35 \%$. The electro-winning process required $2-2.7 \mathrm{kWh} / \mathrm{kg}$ in 1955 [Shreve 1956] and $1.9-2.4 \mathrm{kWh} / \mathrm{kg}$ in 1977[Gaines 1980]. Improvements since then have probably reduced it to around $1.5-1.7 \mathrm{kWh} / \mathrm{kg}$. Data on electrowon production is from the US Bureau of Mines ([USBuMines 1988], "Copper", Table 3).

According to Census of Manufacturing data, electric power consumption by the copper industry for all purposes was 2.8 bkwh in 1947, 3.1 bkwh in 1954, 3.3 bkwh in 1958, 4.4 bkwh in 1962 and 5.7 bkwh in 1967[Garvey and Gelb 1974]. Recent data from the Department of Energy combines the requirements for all metals into a single aggregate sector, primary metal industries (SIC 33), which is dominated by iron and steel.

Table A-9 summarizes the available data on copper production and electrolytic refining.

\subsection{Zinc refining}

The old retorting process has been almost entirely replaced in recent years by electrolytic refining, which now accounts for over 80 percent of worldwide production The process is almost exactly the same as the electro-winning process for copper. Unfortunately we have no specific information on the electric power consumption for this purpose. 


\section{Electronic communications and signal processing}

A use category that was always ignored and relegated to "miscellaneous" is the use of electric power to process electromagnetic signals and to generate and receive electromagnetic radiation (other than visible light). The first such application was the electric telegraph, followed by the telephone (c. 1880), the radio-telephone (c. 1900) and radio broadcasting (c. 1922). Radio technology boomed in the late 1920s. The Radio Corporation of America (RCA) was probably the most overpriced stock on the NY Stock Exchange just before the crash in 1929. However, the telephone switching system was probably the dominant user of electric power in this category. We assume that this would fall into the "Miscellaneous Power and Light" category of Historical Statistics, where transport and street lighting also belong. ${ }^{3}$ For the years before 1922 we assumed that 40 percent of the unallocated Miscellaneous Power and Light (after deleting the known consumption for transport and streetlights) was attributable to telephone switching. After 1922 we assumed that the telephone system consumed one third of the unallocated fraction of this miscellaneous category.

We realize that these assumptions are somewhat arbitrary, but they are not unreasonable. One of the pointers is the fact that AT\&T's Bell Telephone Laboratories undertook the research leading to the transistor as a direct response to rising demand for telephone services. Projections made by AT\&T in the late 1930s and early 1940s indicated that electricity requirements for switching would, within a couple of decades, take an unacceptably large share of the total US electricity supply. Nevertheless, the quantities implied by our own simplistic estimate are small — perhaps too small.

Television arrived just before World War II, and during the 1950s it became an industry in itself. Computers and radar also came after the war. VCRs, DVD players, and PCs have become very important in recent years. Estimates for TV consumption from 1949 to 1958 was based on TV power requirements times the number of homes with TV [Schurr and Netschert 1960] Table C-22. Data from 1978 on was from EIA's publication Annual Energy Reports (Table 2.6).Intervening years were interpolated.

The most reliable data is from EIA surveys since 1991. The Buildings survey in 1995 was helpful [USEIA Buildings 1990; BEC 1995; USEIA Buildings 1996]. Similarly we used the Manufacturing Energy Consumption (MEC) Surveys for 1991, 1994 and 1998 [MEC 1991; MEC 1994; MEC 1998], summarized in Table 3, where the column labeled net demand for "other non-process use" also provides an upper limit. The most important single source was the Residential Energy Consumption (REC) survey of 1997[REC 1997], which gave a detailed breakdown by type of appliance. Recent rates of growth account for increases since then. Internet servers and switching centers have also become large consumers of electric power, some even having their own generating plants.

Table A-16 summarizes our estimates for electronic uses of electric power. The rapid rate of increase in recent years is significant. Our estimate, while based on aggregated data, is roughly consistent with recent studies carried out by the Lawrence Berkeley Laboratory of

3. The miscellaneous category is never defined adequately, but we assume (more or less by process of elimination) that consumption of electricity by non-electric utilities (water, sewage treatment, gas distribution, etc.) belongs there, along with military and government uses that are not elsewhere classified. The "losses and use unaccounted for" category is much larger. It apparently includes transmission losses, but what else is there, or not there, remains mysterious. 
the US Department of Energy [Norford et al 1990; Kawamoto et al 2002; Koomey et al 1992; Mitchell-Jackson et al 2003]

\section{DC electric motors for traction and transport}

As of the end of 1887 there were 8 electric railways in the US of various lengths, averaging 8 cars. The longest was 13 miles long with 12 cars [Hammond 1941]. The official start of the electric traction revolution was 1988, when Frank Sprague built and operated a system in Richmond Va. His cars each had two motors of $7.5 \mathrm{hp}$ operating at 450 volts, DC. That system was 12 miles in length, and included 40 cars, of which 30 had to be capable of operating simultaneously. The Richmond system was not fully successful, due to excessive wear on the metal commutator brushes requiring almost daily replacement. The ThomsonHouston Co. built a four mile line in Allegheny City, Pa, up a steep hill, also in 1888. This system was also not fully successful, for the same reason. Luckily the commutator problem was solved the next year (by carbon brushes) and the electric traction industry exploded.

In 1890 the US had 5700 miles of urban tramways, served by 28,000 tramcars and pulled by 105,000 horses and mules. (There were also 488 miles of cable railways, modeled on the San Francisco system.) By 1 February 1891 there were 151 electric street railways operating or under contract, with 1578 cars over 1252 miles of lines. Exactly two years later ( 1 February, 1893) there were 435 companies, operating 8386 cars over 4927 miles of lines [Hammond 1941]. The Census of Street and Electric Railways in 1902 revealed that the US had 22,000 miles of electrified street railways in service, against only 250 miles of track still served by horse drawn cars [Encyclopedia Britannica 1955 ed. "Tramway"].

The street railway industry discussed above was the first application electric motor drive. Elevators followed quickly. In fact, it was Frank Sprague, again, who organized the first company to make electric elevator drives for skyscrapers. The first six of Sprague's electric elevators were sold to the Postal Telegraph building in New York City in 1892 [Hammond 1941].One of the first electric locomotive applications (1895) was a set of 3 electric locomotives (360 hp) designed especially to operate in a tunnel for the Baltimore and Ohio Railroad under the city of Baltimore, where the smoke from steam locomotives had become intolerable [Hammond 1941]. Other early applications of electric trains were for the metropolitan West Side Elevated railway of Chicago (1895), a branch line of the New York, New Haven and Hartford railway (1895). By the end of 1896 GE alone had produced and sold 9000 generators with a total capacity of 400,000 horsepower, plus 6000 railway motors and $8000 \mathrm{hp}$ in stationary motors [ibid]. The generators essentially averaged a little over 40 $\mathrm{hp}$ and the motors (mainly DC) were comparable in power output.

A control system Sprague developed for the elevator application turned out to be the solution to control problems for multi-car electric trains. This was successfully demonstrated on the 240 motors of the South Side Elevated Railway of Chicago, in 1899 [Hammond 1941]. This success led to the electrification of the Manhattan Elevated railway, which at that time used several hundred steam engines, leaving a permanent pall of smoke over central Manhattan. The initial installation included 1700 traction motors. That job began in 1900 and took several years to complete. Soon after, New York City banned the use of steam engines within the city (because of the smoke problem) and forced the electrification of all railway lines in the city, including marshaling yards. As a practical matter this required electrification of the suburban lines as well. By 1908 the New York Central Railway was eventually electrified as far north as Croton-on-Hudson, using 30 of the same type of locomotive first 
built for the Baltimore and Ohio tunnel. The Interborough Rapid Transit System (IRT) in New York City was electrified during the same time period. The other two lines, Brooklyn Manhattan transit (BMT) and Independent (IND) followed soon after.

During this period of rapid expansion tramways were operating at higher load factors than they were able to achieve later when the capacity had increased enormously. Street railways were much cheaper to build than conventional railways (to say nothing of subways or elevated systems) and by 1900 in most urban areas they the only available means of transport for distances between 1 mile and 10 miles. Cities were expanding rapidly at the time into surrounding areas (due to unrestricted immigration) and tramways were evidently profitable enough to attract a great deal of investment.

Tramway construction accelerated early in the 1890s and was well advanced by 1902 . (It probably peaked in 1907-1908). ${ }^{4}$ Most of the early street railways had to provide their own power supplies, before the central electric utilities developed sufficient capacity. In 1902, non-utility generators generated more power (3.462 bkwh) than central utilities ( $2.507 \mathrm{bkwh})$. In 1907 non-utility generation was 8,259 bkwh vs. 5.862 bkwh by central utilities. In 1912 the non-utility generation had increased to $13.183 \mathrm{bkwh}$, vs. $11.569 \mathrm{bkwh}$. Not until 1917 did central utilities overtake non-utility power generation. On this basis, we can therefore tentatively allocate most of the non-utility contribution to electric traction.

From 1902 to 1917 the system continued to expand rapidly. Municipal tram and street railway use are included within the "miscellaneous light and power" category (with other uses, such as street-lighting) but there is reason to suppose that electric street railways were the major user in that category, in the first two decades of the $20^{\text {th }}$ century. The first year for which data are available was 1912, when miscellaneous light and power accounted for 6.67 bkwh. Of course, some urban tramways had access to central utility power, even in 1900. For instance, Buffalo Traction lines contracted with the Niagara Falls Power Co. in 1896 for $10,000 \mathrm{hp}$ or $0.746 \mathrm{~kW}$, to be increased soon to $40,000 \mathrm{hp}$ or $30,000 \mathrm{kWh}$. After 1912 , central utilities - with increasing economies of scale in their favor - provided an increasing fraction of traction power.

By 1917 the tramway route mileage had doubled to between 40,000 and 45,000 miles and there were between 70,000 and 80,000 cars in service [Encyclopedia Britannica 1955 ed. "Tramway"]. In 191714.5 billion passengers were carried [Hist. Stats. Table Q-42]. Peak use occurred in 1923 when 15.65 billion passengers were carried. (At the time, it has been said, one could travel from Boston to Chicago by street railway, although the trip would have required many changes and many days to accomplish.) By that time, of course, there was rapidly increasing competition over the longer routes from suburban railroads (which also peaked about the same time), automobiles and motor buses, while the larger central cities were building underground or elevated lines to accommodate heavy demands for intracity traffic.

Class 1 railroads were electrified in some heavy traffic corridors from 1900 to 1930 , due to significant advantages over steam power. The elimination of smoke and fumes in tunnels was the initial driver of change, and accounted for the earliest applications in Baltimore and New York City. However, DC electric motors have significant overload

4. In 1894 the power load for stationary and traction motors was only $10 \%$ of total electricity demand in Berlin. By 1900 the traction load alone equaled all the rest. [Hughes 1983] p.188. 
capacity enabling better acceleration. This, together with flexibility of control over multiple unit trains, led to application in suburban passenger service, such as the Long Island, Lackawanna, Illinois Central, and Reading lines. Moreover, by providing motors on each axle, the weight of the train is spread over many driving wheels thus providing better adhesion to the track and use on steeper grades. All of these advantages to electrification of trunk lines with heavy traffic, such as the Pennsylvania Railroad and the New Haven and Hartford line from New York to Boston, as well as some western lines. In 1930 there were 4800 miles of electrified Class I railways in the US, increasing to 6062 miles by 1953 . One line (Norfolk and Western) abandoned electric operation in favor of diesel electric, during the 1950s. The number of electric locomotives in service increased from 300 to 600 from 1930 to 1950, although the number of multiple unit (passenger) cars remained roughly constant at 2000 [Miller 1955]. However many suburban railway lines were abandoned in the 1950s, 1960s and 1970s, until the remnants - mostly in the eastern corridor between Washington DC and Boston - were incorporated into Amtrak.

We have solid data on electric power consumption per passenger $\mathrm{km}$ for electrified Class 1 railways only for 1945, 1950 and 1955 (see Table 4), by which time the suburban passenger railways were rapidly being displaced by buses and private automobiles.

Total electricity consumption by electrified rail systems of all types is summarized in Table A-3. This category accounted for nearly $30 \%$ of national electric power consumption in 1902, but declined rapidly as a fraction of the total. Since 1955 transport use has been less than $1 \%$ of the total and is currently under $0.15 \%$ in the US. However in Western Europe and Japan most railroads are electrified, whence the transport fraction is far higher.

The efficiency of the motor drives is difficult to estimate, but probably it did not change very much after 1930, since there was very little investment in new equipment after that, except for Amtrak, Bay Area Rapid Transit (BART) and a few other systems. We assume that the average efficiency of the DC traction drive motors might be as high as $80 \%$ for periods of continuous operation, but much lower for variable load operations using rheostats for voltage control. An estimate from 1968 gave the efficiency of mobile motive power applications (e.g. railroads) at $65-85 \%$ for Europe [Adams \& Miovic 1968; UNECE 1976a]. For non-transport applications requiring short stop-start cycles, such as elevators or trams, AC "squirrel cage" induction motors are now preferable, using electronic controls. This innovation cuts losses significantly, but we have no specific data.

\section{Electric motors, non-transport uses}

We have disaggregated electric power use by function (sections above) as far as the published data permits. Yet the 'unaccounted for' remainder (which we attribute to electric motor drive), in the year 2000, was $56.6 \%$ for the residential sector, $46.2 \%$ for the commercial sector, $72.4 \%$ for the industrial sector and $54.9 \%$ for the 'unallocated' sector (which is mainly streetlights and telecommunications and miscellaneous military.) Refrigeration and cooling accounted for $26.5 \%$ of residential use, (leaving $30 \%$ for "other") and $24.5 \%$ of commercial use, leaving $21.7 \%$ for "other". Non-transport applications are now overwhelmingly of the AC induction type, which can use power directly from the 120 Volt (220 V in Europe) utility feeds.

Somewhat better data for motor use exists for the European Union, and with some exceptions (such as the greater use of electricity in rail transport), it may be roughly 
applicable to the US also. For six countries (Denmark, France, Germany, Italy, Portugal and the UK) motors account for $69 \%$ of electric power consumption by industry and $38 \%$ by the service sectors (including transportation) [Almeida et al 2003]. In Europe over $90 \%$ of electric power consumed by motors (except for traction and railways) is now attributable to the AC induction type, for the same reasons as noted above for the US.

Although the first motor drive systems in the US were used for traction (and elevators) factory use soon followed. One important point must be emphasized: each early application, whether to a ship, a street railway, a mine or a factory, had to be a self-contained system including a generating plant, a distribution system, motors and controls. Each of these self-contained systems was custom-engineered. Most major cities (except Pittsburgh and Buffalo) were located too far from early sources of large-scale hydroelectric power to take advantage of its lower cost (which is why most of the urban street railways had their own generating plants.) For this reason, too, there was little effort to standardize.

Similarly, most of the early factory applications were stand-alone systems replacing hydraulic power installations with their complicated belt-drives. The efficiency with which water power could be converted by impulse turbines or Pelton wheels to electric power by 1890 was already of the order of $60 \%$ or so. (By $196790 \%$ efficiency was routine [Netschert 1967].)The first textile mill to use electric motors from hydroelectric generators was the Ponemah Mills, at Taftville, Connecticut (Jan. 1894)[Clark 1949]. The second mill to do this was at Pondville Massachusetts, two years later. The next two were in South Carolina. By 1905 the New England Cotton Manufacturers Association reported that 175 textile mills presumably just in New England - were using electricity to drive machinery $(140,000 \mathrm{hp}$ or $104,000 \mathrm{~kW}$ )[Clark 1949]. Obviously textile mills located on or near sources of water power were among the first to convert.

Luckily the AC-DC fight ended in 1896 when GE and Westinghouse came to a patent-sharing agreement and GE adopted the Westinghouse (Tesla) 3-phase AC system for all stationary motor drive applications. By the turn of the century the 3-phase AC system had been established everywhere in the US except the central business districts of big cities where the older DC systems had been installed. Almost 200,000 hp of electric motors was installed in factories by 1900 , although this amounted to only $5 \%$ of the total power consumption by industry at the time [Netschert 1967].

The substitution of electric motors for steam engines in factories proceeded rapidly after 1900. By 1905 or so, however, some urban factories were purchasing electric power from central stations. There is no detailed data on the ownership of the power sources, unfortunately. Data in the first three columns are from [Schurr and Netschert 1960] Table 62, and from Historical Statistics. Data for 1947 are from the Census of Manufacturing, reported in [Woytinsky and Woytinsky 1953], Table 417. Data for 1960 and 1968 from SRI [SRI 1972]. Between 1899 and 1904, additions to the total installed power base (3222 hp) were nearly three times as great as additions to the electric power installed base (1042 hp). From 1904 to 1909 electric motor drive accounted for close to $60 \%$ of the hp additions. From 1909 to 1914, however, the increase in electric motor drive exceeded the total increase, which means that some actual replacement of steam for electric power had begun. Thereafter it can be assumed that no new steam plants were built. However, stand-alone diesel units began to penetrate some industrial sectors in the late 1930s, and increasingly thereafter, mainly for construction and in remote locations such as mines. 
From the 1890s until after World War II, almost all motor drive in industry was for textile mills, rolling mills, paper mills, machine tools, and (increasingly) pumps and compressors. Pumps play a significant role in farming (for wells and irrigation) households and buildings of all kinds, mainly for water circulation (hot and cold). Pumps are essential for urban water treatment and distribution. The major industrial uses of pumps are in mining (the first steam engines were used for draining water from mines), oil drilling, oil pipelines, oil refineries, organic and inorganic chemical operations, sugar mills, breweries and water treatment (among others). All liquid phase operations in the chemical industry depend upon pumps. All kinds of hydraulic equipment, such as fork lifts, stamping machines and metal presses, also depend upon pumps for power. Pumps are also integral components of washing machines and dishwashers in the home, as well as commercial laundries. Oil burners require pumps, as do gasoline filling stations. Pumps are said to account for $20 \%$ of the world's electrical energy demand (UNIDO).Assuming this fraction holds for the US, it would follow that pumping operations must account for over half of all industrial uses of electric power.

Compressors are essential components of all industrial refrigeration and cooling systems, of course. Just as all liquid-phase operations depend on pumps, all gaseous-phase operations require compressors, beginning with long distance natural gas pipelines. A number of chemical production operations require very high pressures. Many chemical processes require high pressures, for instance. (Ammonia synthesis and methanol synthesis are the most familiar examples.)

Compressors are built into gas turbines and turbo-chargers as well as refrigeration and air-conditioning equipment (discussed later). They are also utilized to fill containers for the shipment and distribution of propane, nitrogen, oxygen, hydrogen, helium, argon and other gases, for compressed air-driven machinery, for gas pipelines, large-scale ventilation systems, and gaseous-phase chemical processes. Compressed air is a form of energy storage that is still widely used in industry, especially for drilling.

An extremely large use of electric power by the US Atomic Energy Commission, primarily for compressors, was for the gaseous diffusion, process for separating isotopes of uranium during the 1950s and 1960s. As a matter of interest, the AEC consumed $3.099 \mathrm{bkwh}$ in $1945,3.974$ bkwh in 1950, 14.729 bkwh in 1953, 50.105 bkwh in 1955, 60.655 bkwh in 1956 (the peak year), 56.873 bkwh in $1960,38.707$ bkwh in 1965, and 19.672 bkwh in 1970 , the last year for which we have explicit data. Evidently this 'bulge' resulted in some distortion of the 'motor drive' percentages, especially during the late 1950s.

\subsection{Refrigeration and air-conditioning}

An important application of compressors is for refrigeration and air-conditioning equipment. Large scale refrigeration units first became important since the commercialization of "dry ice" in the $19^{\text {th }}$ century for the preservation and shipping of meat, e.g. from Argentina and Australia to Europe. Quick-frozen fruits and vegetables (beginning with the 'Birdseye' brand) began to appear on grocery shelves in the 1930s, and commercial ice cream soon followed. The cryogenics industry grew very rapidly in the 1950s along with demand for liquid oxygen for the steel industry and (in the 1960s) for liquid hydrogen for rockets. Liquid nitrogen, which became widely available as a by-product of liquid oxygen (separated from air), has now found many markets. Liquefied natural gas (LNG) is also now an important industrial commodity. 
In the commercial and residential domain, electric refrigeration began to replace 'iceboxes' in the 1920s. By $193010 \%$ of US households boasted a refrigerator. Demand expanded very rapidly in the 1930s, after the discovery of chloro-fluorocarbon refrigerants such as 'freon'. By $194270 \%$ of US households were equipped with refrigerators, and by 1950 the penetration had reached $90 \%$. Air conditioning began to follow a similar trajectory in the post-WW II period. Home air-conditioning was rare in 1950 and achieved the 15\% level around 1960. By $197823 \%$ of US homes had central air conditioning (up to $30 \%$ by 1984 ) and $33 \%$ had room air conditioners. Today air conditioning is regarded as essential for living in hot climates, and most homes and commercial buildings (and automobiles) were equipped with air-conditioning by the late 1980s. However, there are no explicit published data on industrial cooling (air-conditioning and refrigeration) prior to 1991.

The percentages for residential and commercial use shown in the table are calculated from published data from the Energy Information Administration for 1978, 1980-1984 inclusive, 1987, 1990, 1993, 1997 and 1999. Residential consumption uses were reported in Annual Energy Reviews [USDOEEIA annual] various years and 2001 BTS Core Databook [BTS 2001]. But it must be recognized that the surveys from which these percentages are derived all have very large "unreported" fractions. Normally one assumes that the allocation of unreported uses is the same as the reported uses, but this assumption is not always reasonable. In particular, the 1997 reported data on residential air-conditioning was anomalously low (lower than reported use in 1987, 1990 and 1993), while "other" uses were anomalously high for that year, so we took the liberty of interpolating $\mathrm{A} / \mathrm{C}$ usage between 1993 and 1999.

Survey data on commercial use were not available for the same years as for residential use. EIA provides data for 1989 ([USEIA Buildings 1990] Table 4.8), 1995 ([USEIA Buildings 1996] Table EU-3) and 1999 ([BTS 2001] Table 1.3.3). For the years 1989 and 1995 it was necessary to use residential consumption data interpolated between 1987 and 1990 for 1989, and between 1993 and 1997 for 1995, combined with data on commercial use for the three specified years. The commercial data for 1989 included no explicit figure for commercial refrigeration, but since there was no change from 1995 to 1999, it seemed reasonable to assume that 1989 refrigeration use would have been very similar, since virtually $100 \%$ of households have had refrigerators since the 1950s. (Penetration was $97.3 \%$ in 1958 , and $99 \%$ by 1965.$)$

Air-conditioning now accounts for considerably more electric power than refrigeration, but this was not true in the early postwar decades, when air-conditioning was a luxury, reserved for theaters, restaurants, hotels and department stores. Even now, residential use of electricity for refrigeration exceeds use for air-conditioning by a significant margin. In commercial and office buildings, of course, it is air-conditioning that dominates in terms of power consumption.

Air conditioning and refrigeration systems are virtually the same, as regards the components - thermostats, motor controls, compressors, and heat exchangers. The key difference is that refrigerators and freezers are enclosed and insulated volumes. The so-called energy crisis of 1973-74 attracted attention to operating costs for the first time, and prompted the State of California to introduce efficiency standards for refrigerators. In 1987 the US government extended the California standards nationwide and they were renewed and extended in 1990. The energy crisis also triggered the creation of several new energy-related research centers including the Electric Power Research Institute (EPRI) in Palo Alto (funded by the electric utilities) and the Lawrence Berkeley Laboratories of the University of 
California, funded by the newly created Department of Energy. Energy consumption statistics for home appliances was gathered by these research organizations (by survey) from 1978 on.

The standard measure of performance for a refrigerator (or freezer) is $\mathrm{kWh} / \mathrm{volume}$ day. Obviously performance can be improved by increasing the enclosed volume, which reduces the surface to volume ratio and consequently the rate of heat leakage, all other factors remaining the same. Heat leakage can also be reduced by improving the thermal insulation. Refrigerator performance did improve radically in the 1960s, thanks to the introduction of 'super' insulation, consisting of plastic foam formed in a vacuum or impregnated with chlorofluorocarbons.

Information from the Swedish appliance manufacturer Electrolux suggests that electric power requirements of its models, as measured in $\mathrm{kWh}$ per 100 liters of volume, per 24 hour day fell by a factor of 7 in its first decade, from about $3.8 \mathrm{kWh}$ for 1958 models to $0.5 \mathrm{kWh}$ for the 1968 model. From 1969 to 1988 the improvement was much slower but still significant (from 0.5 to $0.3 \mathrm{kWh}$ ) and the rate of improvement has apparently accelerated. The 1993 model achieved close to $0.1 \mathrm{kWh}$. While this is not a theoretical limit, it is probably close to the practical limit for household refrigerators of reasonable size.

In fact, this example illustrates a difficulty in efficiency measurement, since, for a very large unit with perfect thermal insulation the limiting case is obviously zero. We have no information on the actual thermal efficiency of cooling equipment prior to 1972. However a relative energy efficiency measure (EER) can be obtained by inverting the power consumption measure above. In 1972, refrigerators and freezers in the US were estimated to have EERs of 3.84 and 7.29 cubic foot-days per kWh, respectively. (Freezers (in homes) are more efficient per cubic volume because on average they are opened much less frequently to the outside air.) Air-conditioners can be rated in a similar manner, based on a standard volume of space being climate-controlled, adjusted for the fact that air-conditioning is seasonal, hence not required year round. In 1972 Central and room air-conditioners had seasonal EERs (SEERs) of 6.66 and 5.98, respectively.

According to one study, both types of air-conditioners increased SEER by 10-12 percent from 1972 to 1978 , the first year for which actual survey data were available [McMahon 1991]. Thereafter the improvement was slightly faster, as consumers became more sensitive to operating costs and manufacturers were able to implement more fundamental design improvements (mainly in the controls). By 1987, both room and central air-conditioning systems had improved (on average) by about $33 \%$, and the trend was continuing.

Surprisingly, refrigerators and freezers improved much faster. According to the same source, EERs had increased by 29\% and 36\% respectively from 1972 to 1978, and by $94 \%$ and 88\%, respectively, by 1987 [McMahon 1991]. This differential between refrigerators and air conditioners could be partly due to better insulation, but the more plausible explanation is that refrigerators and freezers started from a lower point, designs having been standardized for mass production much earlier. There is reason to believe that refrigerator technology per $s e$ - apart from better insulation - had not changed significantly since the 1930s, given that it was not visible to consumers. There were no direct measures of average power consumption available to consumers, and competition between brands was based mainly on price, appearance, enclosed volume and special features (e.g. ice-cube makers). 
Another study by EPRI, set the electricity consumption by a typical refrigerator in 1972 at $1726 \mathrm{kWh} / \mathrm{yr}$ [EPRI 1993]. By 1978 this had fallen to 1453, and thereafter to 1140 (1984), 930 (1990) and 690 (1993). These figures correspond approximately to the percentage improvements cited by McMahon, but the series is longer and it has been explicitly extrapolated down to 580 (1998). We assume that the trend has continued along the same trajectory, which suggests an average power consumption (for new refrigerators) of about $500 \mathrm{kWh} / \mathrm{yr}$ by 2000 . This corresponds to a remarkable $340 \%$ increase in the service output of new refrigerators since 1972. Of course the average lifetime of refrigerators in service is quite long (about 15 years) so the performance improvement for the national stock of refrigerators lags behind by 7 or 8 years, but even so it appears to have trebled during the last three decades. In the case of air-conditioners the improvement is far less dramatic, but nevertheless significant. We have not found specific data for the years since 1987, but if the prior trend continued the overall stock would have increased efficiency by around $50 \%$.

\subsection{Other motor drive, unallocated.}

As noted previously, the major unallocated uses of electric motors are for pumps, compressors and machine tools. Compressors used in refrigeration and cooling equipment have been discussed above. Motor-driven production machine tools, such as rolling mills (for metals or paper), high speed printing presses, looms, cutting and drilling tools, shears, and grinding machines are the third major sub-category. Unfortunately, except for the AEC, there are no data (that we know of) to quantify the subdivision of industrial motor drive among the three major categories of pumps, compressors and production machine tools. Table A-14 summarizes our data for motor drive in the US. The data are plotted graphically as percentages of overall motor use in Figure 3.

In the residential and commercial sectors there are many motor-driven devices, apart from water pumps, refrigerators and air-conditioners. They include ventilating fans, washing machines and dishwashers, clothes driers, vacuum cleaners, mixers, lawn mowers, power tools, toys, record players and PCs. Vehicles of all kinds also contain a great many electric motors, although the electric power they consume - is generated on-board and attributed to the fuel consumption of the vehicle.

As noted previously there is detailed recent data on motor use for six major countries in the European Union, c. 2000 [Almeida et al 2003]. Within the industrial sector the breakdown is as follows:

$\begin{array}{lr}\text { Air compressors } & 18 \% \\ \text { Cooling compressors (including refrigeration and air conditioners) } & 7 \% \\ \text { Fans } & 16 \% \\ \text { Pumps } & 21 \% \\ \text { Conveyors } & 2 \% \\ \text { Other uses } & 16 \%\end{array}$

Within the service sectors (including commercial establishments and transport, but not residences) the breakdown is as follows" 


$\begin{array}{lr}\text { Refrigeration } & 25 \% \\ \text { Air conditioning } & 17 \% \\ \text { Fans (ventilation) } & 24 \% \\ \text { Pumps } & 16 \% \\ \text { Conveyors } & 11 \% \\ \text { Other uses } & 7 \%\end{array}$

Motor efficiencies vary considerably according to power and duty cycle. Small motors $(<0.75 \mathrm{~kW})$ range from $57 \%$ to $75 \%$ efficiency (average about $65 \%$ ), whereas large heavy duty motors $(>130 \mathrm{~kW})$ achieve efficiencies as high as $96 \%$ [Almeida et al 2003].Such a high figure presumably refers to so-called 'hi-efficiency' motors being introduced in the early 1980s, with solid state electronic controls. These motors made possible savings from $30 \%$ to $50 \%$ as compared to earlier electro-mechanical controls [Martiny 1984]. Obviously, a $50 \%$ savings would correspond to doubling the original motor efficiency, from which it follows that some (at least) earlier industrial motors were less than $50 \%$ efficient. A $30 \%$ savings would correspond to an original efficiency of around $70 \%$. Clearly the range is large, but it seems likely that industrial motors in the 1970s averaged around 60\% efficiency, probably not much better than motors built at the beginning of the century. Improvements since then may have brought the average up to $75 \%$ or so. In all cases, variable loads result in significant losses if traditional speed controls by resistive voltage regulation (using rheostats) are used.

\section{Summary; Secondary efficiency and opportunities for improvement}

The efficiency with which electric power has been converted to visible light, since Edison's original carbon-filament lamps has been calculated and the relevant historical data have been compiled by Nordhaus [Nordhaus 1994b]. The efficiency of electric lighting has increased significantly, since 1900. Incandescent lamps at the time were about $1 \%$ efficient (based on 400 lumens/watt). By 1970, the efficiency of incandescent lamps had risen to 5\% (with much of the improvement taking place between 1905 and 1910, due to the introduction of tungsten filaments). There was not much improvement after 1930. Fluorescent lamps, introduced in the 1930s, were about 8\% efficient in 1940 and 20\% efficient by 1970 [Summers 1971]. According to General Electric Co. (quoted by Summers), fluorescent lamps provided $70 \%$ of total illumination in 1970, while incandescent and 'high intensity' lamps split the remainder. This works out at $13 \%$ overall efficiency for that year.

However, a more detailed calculation in the late 1980s concluded that the average output of incandescent, fluorescent and high intensity lamps was 16, 66 and 48 lumens/watt, respectively, for an overall average of 44 lumens/watt or $11 \%$ average efficiency, slightly below the Summers figure cited above [Lovins and Sardinsky 1988]. However the two figures are not dramatically different. So-called compact fluorescent lamps (to replace incandescent lamps) have been introduced since the 1980s, but the market penetration of these units is still small.

As regards high temperature heat, we can assume that electric arc furnaces are representative (although there are other types, notably coreless induction heaters) and it seems safe to assume that improvements since the early days have been modest at best. The basic technology has not changed, and the furnaces have simply grown a bit larger, with some economies of scale. We somewhat arbitrarily assume that the original arc furnaces were 
80 percent efficient at delivering high temperature heat where it was needed, and that this efficiency may have increased to $90 \%$ today. Much lower figures apply to water heating, of course but the rate of improvement has not been significantly better. The major change has been in cooking, where microwaves have made a significant improvement, but only for a small part of the overall usage. Overall, however the major change is that demand for low temperature heating has increased far more than demand for high temperature heating.

In the case of electrolytic processes, we were guided by the two examples for which we have long-term data series, namely aluminum and chlorine. In the case of aluminum, we estimate that the efficiency of the electrolytic cells have improved from $13 \%$ to about $40 \%$ of the theoretical maximum (a factor of 3), although solid information is only available for the period since 1925. In the case of chlorine, the improvement may have been comparable, but probably a little less. In the case of other chemicals and metals the quantities produced would generally not have justified independent $R \& D$ efforts, whence we assume that the manufacturers of the capital equipment would have benefited from most, but perhaps not quite all, of the technical improvements achieved in the aluminum case.

As regards electronic applications, the efficiency improvements have not been measured in a straightforward way, although a possible metric (kilobytes or megabytes per kilowatt) suggests itself. However, the performance gains have clearly been enormous many factors of ten. On the other hand, further gains are expected to be large for many years in the future, which implies that current signal processing efficiency is still extremely low, perhaps much less than $1 \%$. Even if signal processing efficiencies have already improved by a very large factor - greater than 1000 - the amount of (secondary) physical work done by this technology is still quite small, (See Figures 5 and 6 below). Hence, inaccuracies in the efficiency estimation do not have a major impact on our overall results. However, looking forward ten or twenty years a different conclusion might be warranted.

The biggest end-use category, by far, is electric motors (Figure 2). Large DC motors, such as used in transit and rail systems have not changed very much, except that windings have improved somewhat and voltage control systems have improved significantly in the past two or three decades. We estimated $60 \%$ in $1900,70 \%$ by 1930 and $85 \%$ today. These figures probably also apply to large industrial motors, including motors for pumps and compressors. There has been a more significant change in the efficiency of small AC induction motors such as are found in kitchen appliances, washing machines and the like. Here the improved electronic frequency controls make a bigger difference. We guess (nothing more precise can be claimed) that the efficiency of such small motors in constant speed applications, e.g. in washing machines, refrigerators or vacuum cleaners, was $70 \%$ in 1900 and $85 \%$ today. This also applies to air conditioners in the household sector. The average power output of motors has certainly declined since 1900, due to the large number of applications of very small motors in household appliances. On the other hand, controls have improved.

N.B. we have not attempted to estimate the efficiency of complete systems such as pumping systems, compressors, refrigeration systems. or machine tools. Significant improvements have taken place in some of these areas, but we have no data. Our estimates are summarized in Table 5. The intervening years have been interpolated, which appears to be adequate for the purpose, and plotted in Figure 4.

The last step is to calculate the overall efficiency of performing secondary work done by electric power. The calculation is very straightforward, namely the product of the 
efficiency figure in each column (function) by the total amount of electric power consumed in performing that function. The most interesting (and perhaps surprising) result - also plotted in Figure 4 - is that even though each end use has become more efficient over time, the overall efficiency of electric power use has scarcely changed since 1900 . The reason for the counter-intuitive result is that the mix of applications has simultaneously changed. Efficiency increases in some applications - especially very sharp gains in electric lighting and electronic signal processing - are largely overcome, in the overall picture, by the sharply increased use of electricity for low temperature heat, which is extremely inefficient. It follows that this application offers the most promising opportunity for future gains.

The results are also expressed as percentages of total secondary work performed by electricity. They are plotted graphically in Figure 5 and Figure 6. All results for each functional enduse are shown by decade in Table 6 and the same data for the entire time range are given in Table A-17. 


\section{References}

[Adams \& Miovic 1968] Adams, F.G. and P. Miovic, 1968. "On relative fuel efficiency and on the output elasticity of energy consumption in western Europe." Journal of Industrial Economics XVII (November).

[Almeida et al 2003] Almeida, Anibal T., Paula Fonseca and Paolo Bertoldi, 2003. "Energy-efficient motor systems in the industrial and in the service sectors in the European Union: characterization, potentials, barriers and policies." Energy - The International Journal June 200328 (7): 673-690.

[Altenpohl 1982] Altenpohl, Dieter, 1982. Aluminum viewed from within Dusseldorf, Germany, AluminiumVerlag.

[APS 1975] Carnahan, Walter, Kenneth W. Ford, Andrea Prosperetti, Gene I. Rochlin, Arthur H. Rosenfeld, Marc H. Ross, Joseph E. Rothberg, George M. Seidel and Robert H. Socolow, 1975. Efficient use of energy: A physics perspective. New York: American Physical Society: January. Study Report:399.

[Atkins et al 1991] Atkins, Patrick R., Don Willoughby and Herman J. Hittner, 1991. Some energy and environmental impacts of aluminum usage. Energy and the Environment in the 21st Century. Jefferson W. Tester, David O. Wood and N. A. Ferrari. Cambridge MA, MIT Press.

[Ayres 1989b] Ayres, Robert U., 1989. Energy inefficiency in the US economy: A new case for conservatism. Laxenburg, Austria: International Institute for Applied Systems Analysis: November. Research Report:RR-89-12.

[Ayres and Scarlott 1952] Ayres, Eugene E. and Charles A. Scarlott, 1952. Energy sources the wealth of the world New York, McGraw-Hill.

[Ayres and Warr 2002] Ayres, Robert U. and Benjamin Warr, 2002. Economic growth models and the role of physical resources. Unveiling wealth: On money, quality of life, and sustainability. Peter Bartelmus. Dordrecht/Boston/London, Kluwer Academic Publishers: 171-188.

[Ayres and Warr 2003] Ayres, Robert U. and Benjamin Warr, 2003. "Accounting for growth: the role of physical work." Structural Change and Economic Dynamics (submitted).

[Ayres and Warr 2003] Ayres, Robert U. and Benjamin Warr, 2003. "Exergy, power and work in the US economy 1900-1998." Energy-The International Journal March.

[Ayres and Warr 2003] Ayres, Robert U. and Benjamin Warr, 2003. Useful work and information as drivers of growth. Fontainebleau, France: INSEAD: INSEAD Working Paper:2002/121/EPS/CMER.

[Barbier 1976] Barbier, Marcel, 1976. A survey of electric technologies: Electric heat treatment of metals. McLean VA.: MITRE Corp, METREK Div.: May 1976. Technical report:MTR-7209 Series 9.

[Barbier et al 1976] Barbier, Marcel, Mary Harlow, Robert Ouellette and Robert Pikul, 1976. A survey of electric technologies: Acetylene production by electric means. McLean VA.: MITRE Corp, METREK Div.: June 1976. technical report:MTR-7209 series 1.

[BEC 1995] United States Energy Information Agency, 1995. Electricity consumption in buildings 1995, United States Energy Information Agency. 2002

[BTS 2001] United States Department of Energy, 2001. BTS Core Databook. Washington DC: United States Department of Energy.

[Burke 1978] Burke, James, 1978. Connections Boston MA, Little Brown and Company.

[Burwell and Reister 1985] Burwell, C. C. and D. B. Reister, 1985. Electricity use trends in the production of chemicals. Oak Ridge TN: Institute for Energy Analysis, Oak Ridge Associated Universities: 81: August. Research memorandum:ORAU/IEA-85-4(M).

[CEN 1990] Anonymous, 1990. "Production by the US chemical industry." Chemical and Engineering News June 27.

[CEN 1991] Anonymous, 1991. "Production by the US chemical industry." Chemical and Engineering News June 29.

[CEN 1992] Anonymous, 1992. "Production by the US chemical industry." Chemical and Engineering News June 29: 39ff. 
[Clark 1949] Clark, Victor S., 1949. History of manufactures in the United States New York, Peter Smith.

[Considine et al 2000] Considine, Timothy J., Christopher Jablonowski and Donita M. M. Considine, 2000. "The industrial ecology of steel." 32.

[Considine et al 2001] Considine, Timothy J., Christopher Jablonowski and Donita M. Considine, 2001. The environment and new technology adoption in the US steel industry. University Park PA: Department of Energy, Environmental \& Mineral Economics: 120: May 15, 2001.BES-9727297.

[EPRI 1993] EPRI, 1993. Palo Alto, Cal.: Electric Power Research Institute: July 7.CSVR2327-19-5/7/93.

[FfE 1999] FfE, 1999. LCA of basic and finished materials: Part III Metals. Munich, Germany: Research Institute for Energy Economics (FfE): March.

[Gaines 1980] Gaines, Linda L., 1980. Energy and material flows in the copper industry. Argonne IL: Argonne National Laboratory.

[Garvey and Gelb 1974] Garvey, Nancy and Bernard Gelb, 1974. Electrometallurgical products. Energy Consumption in Manufacturing. John G. Myers. Cambridge MA, Ballinger.

[Gordian 1975] Gordian Associates, 1975. Energy conservation: The database. The potential for energy conservation in nine selected industries. Washington DC: United States Environmental Protection Agency: Steel; Volume:8.

[Hall et al 1975] Hall, E. H., W. H. Hanna, L. D. Reed, J. Jr. Varga, D. N. Williams, K. E. Wilkes, B. E. Johnson, W. J. Mueller, E. J. Bradbury and W. J. Frederick, 1975. Evaluation of the theoretical potential for energy conservation in seven basic industries. Columbus $\mathrm{OH}$ : Battelle Columbus Laboratories: July 11. Final Report:PB-244,772.

[Hammond 1941] Hammond, John Winthrop, 1941. Men and volts: The story of general electric New York, J. B. Lippincott Company.

[Heap 1983] Heap, R. D., 1983. Heat pumps: unknown: Miscellaneous.

[Hughes 1983] Hughes, Thomas Parkes, 1983. Networks of power; Electrification in western society, 1880-1930 Baltimore MD, Johns Hopkins University Press.

[Kawamoto et al 2002] Kawamoto, Kaoru, Jonathan G. Koomey, Bruce Nordman, Richard E Brown, Mary Ann Piette, Michael Ting and Alan K. Meier, 2002. "Electricity used by office equipment and network equipment in the US." Energy - The International Journal 200227 (3): 255-269.

[Koomey et al 1992] Koomey, Jonathan G., C. Calwell, S. Laitner, J. Thornton, Richard E. Brown, Joseph H. Eto, C. Webber and C. Cullicott, 2002. Sorry, wrong number:The use and misure of numerical facts in analysis and media reporting of energy issues. Annual Review of Energy and the Environment. Robert H. Socolow, D. Anderson and J. Harte. Palo Alto, CA, Annual Reviews Inc.

[Lewes 1898] Lewes, Vivian B., 1898. "Acetylene." American Manufacturer 20 January.

[Lovins 1977] Lovins, Amory B., 1977. Soft energy paths: Towards a durable peace Cambridge MA, Ballinger Publishing Company.

[Lovins and Sardinsky 1988] Lovins, Amory B. and Robert Sardinsky, 1988. The state of the art: Lighting. Snowmass CO: Rocky Mountain Institute, Competitek: 332: March.

[Lowenheim and Moran 1975] Lowenheim, Frederick A. and Marguerite K. Moran, 1975. Faith, Keyes, and Clark's industrial chemicals New York, Wiley-Interscience.

[Martiny 1984] Martiny, Walter J., 1984. "Making the choice between normal and hi-efficiency motors." EPRI Journal March.

[McMahon 1991] McMahon, James E., 1991. National appliance efficiency regulations and their impact. Energy and the Environment in the 21st Century. Jefferson W. Tester, David O. Wood and Nancy A. Ferrari. Cambridge MA, MIT Press.

[MEB 1995] The Management Institute for Environment and Business, 1995. Competitive implications of environmental regulation: A study of six industries. Washington DC: for the United States Environmental Protection Agency.

[MEC 1991] United States Energy Information Agency, 1991. Manufacturers energy consumption survey, United States Energy Information Agency. 2002 
[MEC 1994] United States Energy Information Agency, 1994. Manufacturers energy consumption survey 1994, United States Energy Information Agency. 2002

[MEC 1998] United States Energy Information Agency, 1998. Manufacturers energy consumption survey 1998, United States Energy Information Agency. 2002

[Miller 1955] Miller, John A., 1955. Electric Traction. Encyclopedia Britannica,. Chicago, London, Toronto, Encyclopedia Britannica, Inc. 8.

[Miller 1976] Miller, Grant, 1976. A survey of electric technologies: coreless induction heating. McLean VA: MITRE Corp., METREK Div.: April 1976. Technical Report:MTR-7209 series 3.

[Mitchell-Jackson et al 2003] Mitchell-Jackson, Jennifer D., Jonathan G. Koomey, Bruce Nordman and M. Blazek, 2003. "Data center power requirements: measurements from Silicon Valley." Energy - The International Journal June 200328 (8): 837-850.

[Myers 1974] Myers, John G., (Ed.) 1974. Energy consumption in manufacturing Ford Foundation Energy Policy Project (Series). Cambridge MA, Ballinger.

[Netschert 1967] Netschert, Bruce C., 1967. Developing the energy inheritance. Technology in Western Civilization: Technology in the Twentieth Century. Melvin Kranzberg and Carroll W. Jr. Pursell. New York, London, Toronto, Oxford University Press. 2: 772.

[Nordhaus 1994b] Nordhaus, William D., 1994. Do real output and real wage measures capture reality? The history of lighting suggests not. New Haven CT: Cowles Foundation for Research in Economics at Yale University: September. Cowles Foundation Discussion Paper:1078.

[Norford et al 1990] Norford, L., A. Hatcher, J. M. Harris, A. Yoturier and O. Yu, 1990. Electricity use in information technologies. Annual Review of Energy. J. M. Hollander. Palo Alto CA, Annual Reviews Inc.: 423-453.

[Partington 1925] Partington, J. R., 1925. The alkali industry London, Bailliere.

[REC 1997] United States Energy Information Agency, 1997. Residential energy consumption survey 1997, United States Energy Information Agency. 2002

[Ross and Williams 1975] Ross, Marc H. and Robert H. Williams, 1975. Assessing the potential for fuel conservation. Buffalo, N.Y.: State University of New York, Institute for Public Policy Alternatives.

[Schurr and Netschert 1960] Schurr, Sam H. and Bruce C. Netschert, 1960. Energy in the American economy, 1850-1975 Baltimore MD, Johns Hopkins University Press.

[Shreve 1956] Shreve, R. Norris, 1956. The chemical process industries New York, McGraw-Hill Book Company.

[SRI 1972] Stanford Research Institute, 1972. Patterns of energy consumption in the United States. Washington DC: Office of Science and Technology, Executive Office of the President: January.

[SRI 1989a] Stanford Research Institute, 1989. Chemical economics handbook Menlo Park CA, SRI International.

[SRI 1989b] Stanford Research Institute,1989. Chlorine and alkali chemicals. Chemical Economics Handbook, Menlo Park CA, SRI International.

[SRI 2000] Berthiaume, Sylvie, Eric Anderson and Yuka Yoshida, 2000. Chlor-alkali: Chlorine/sodium hydroxide. Menlo Park CA: SRI International: 151: February. CEH Marketing Research Report:733.1000 A.

[Summers 1971] Summers, Claude M., 1971. "The conversion of energy." Scientific American September.

[UNECE 1976a] United Nations Economic Commission for Europe, 1976. Increased energy economy and efficiency in the ECE region. New York: United Nations Economic Commission for Europe: March. Technical Report:E/ECE/883/Rev. 1.

[USBuMines 1967p] Lewis, Richard W., 1967. Phosphate rock. Minerals Yearbook, 1967. Washington DC, United States Government Printing Office. I-II: 949-964.

[USBuMines 1988] United States Bureau of Mines, 1988. Minerals yearbook: 1988 Washington DC, United States Government Printing Office. 
[USBuMines monthly] United States Bureau of Mines, monthly. Mineral commodity summaries. Washington DC: United States Bureau of Mines: through 1996.

[USCensus 1975] United States Bureau of the Census, 1975. Historical statistics of the United States, colonial times to 1970 Washington DC, United States Government Printing Office.

[USCensusMfg 1972] US Department of the Census, 1972. Census of manufactures Washington DC, US Government Printing Office.

[USDOC 1992a] United States Department of Commerce Bureau of Economic Analysis, 1992. Business statistics, 1963-1991. Washington DC: United States Department of Commerce: June.

[USDOEEIA annual] United States Department of Energy, Energy Information Administration, annual. EIA annual energy review Washington DC, United States Government Printing Office.

[USEIA Buildings 1990] United States Energy Information Administration, 1990. Buildings and energy in the 1980s. Washington DC: Energy Information Administration, United States Department of Energy.

[USEIA Buildings 1996] United States Energy Information Administration, 1996. A look at commercial buildings in 1995: Characteristics, energy consumption and energy expenditures. Washington DC: Energy Information Administration, United States Department of Energy.

[USEPA 1971] United States Environmental Protection Agency, 1971. Atmospheric emissions from chlor-alkali production. Washington DC: United States Environmental Protection Agency: Report:AP-80.

[USEPA 1976d] United States Environmental Protection Agency, 1976. Atmospheric emissions from chloralkali production. Washington DC: United States Government Printing Office:AP-80.

[USGS annual] United States Geological Survey, annual. Minerals yearbook. Washington DC: United States Geological Survey: annual since 1996.

[USGS monthly] United States Geological Survey, monthly. Mineral commodity summaries. Washington DC: United States Geological Survey: monthly since 1996.

[USS 1971] McGannon, H. E., (Ed.) 1971. The making, shaping and treating of steel (Series). Pittsburgh PA, United States Steel Corporation.

[Vaughan et al 1976] Vaughan, William J., Clifford S. Russell and Harold C. Cochrane, unknown (c. 1976). Government policies and the adoption of innovations in the integrated iron and steel industry. Washington DC: Resources for the Future Inc.

[Vlahakis and Ouellette 1976] Vlahakis, John and Robert Ouellette, 1976. Survey of electric technologies: electrolysis. Bethesda MD: Mitre Corporation: May. Mitre Technical Report:MTR-7209 Series 10.

[Wehle 1974] Wehle, Mark, 1974. Alkalis and chlorine--SIC 2812. Energy Consumption in Manufacturing. John G. Myers. Cambridge, MA., Ballinger.

[Woytinsky and Woytinsky 1953] Woytinsky, W. S. and E. S. Woytinsky, 1953. World population and production: Trends and outlook New York City, Twentieth Century Fund. 


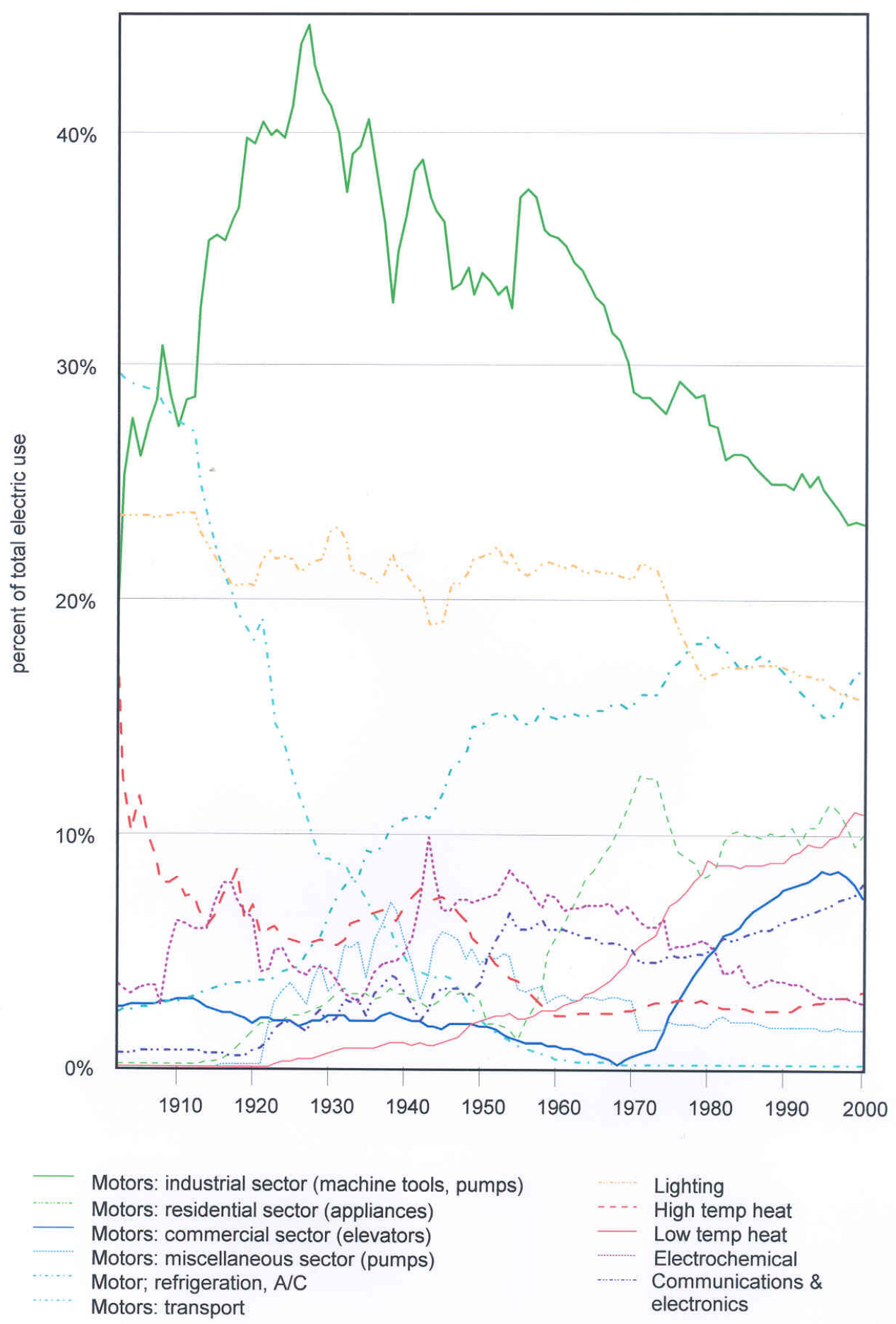

Figure 1: Functional electric use. Percentage of total electric use, USA 1900-2000. 


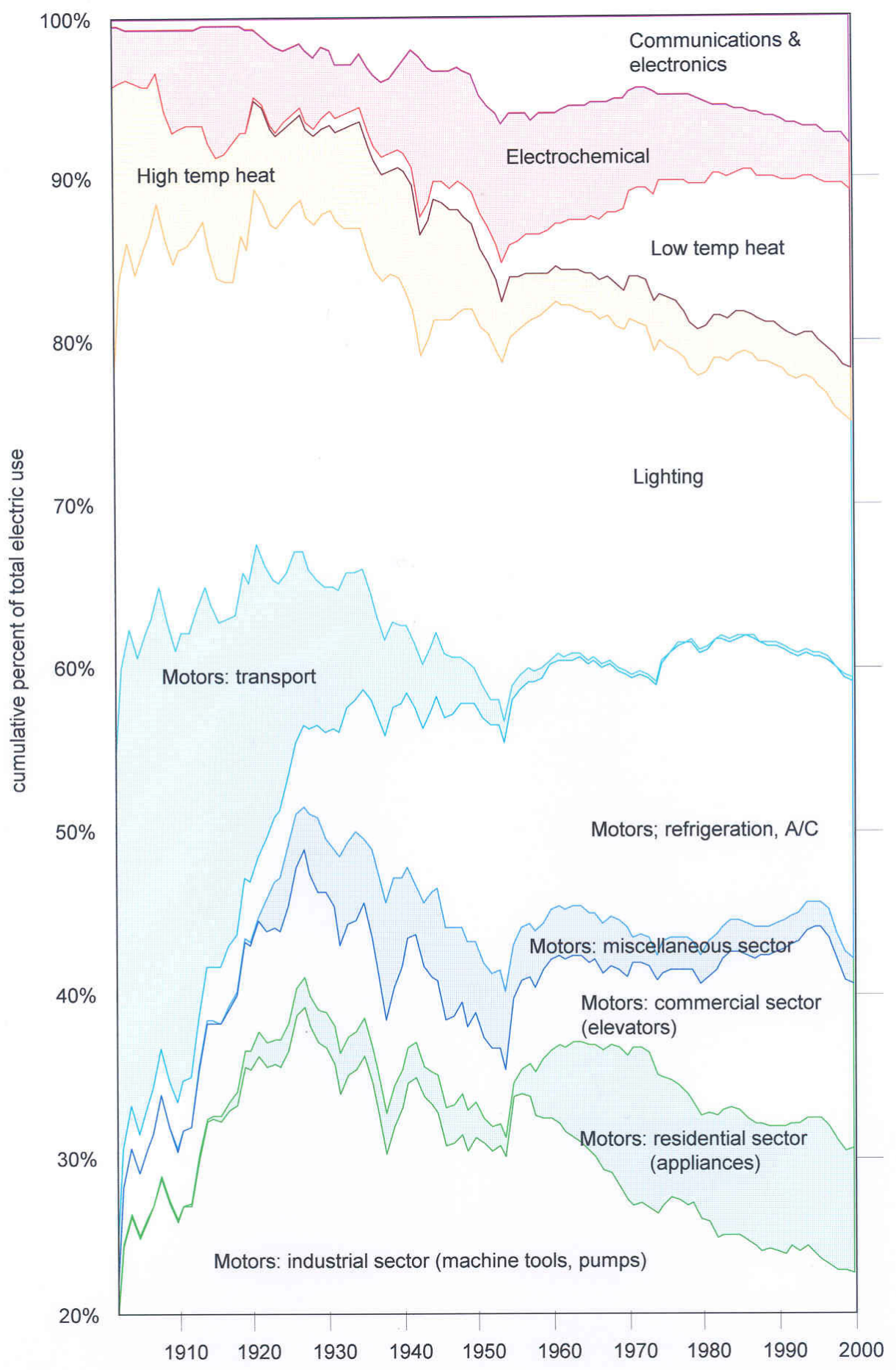

Figure 2: Functional electric use. Cumulative percentage of total electric use, USA 19002000. 


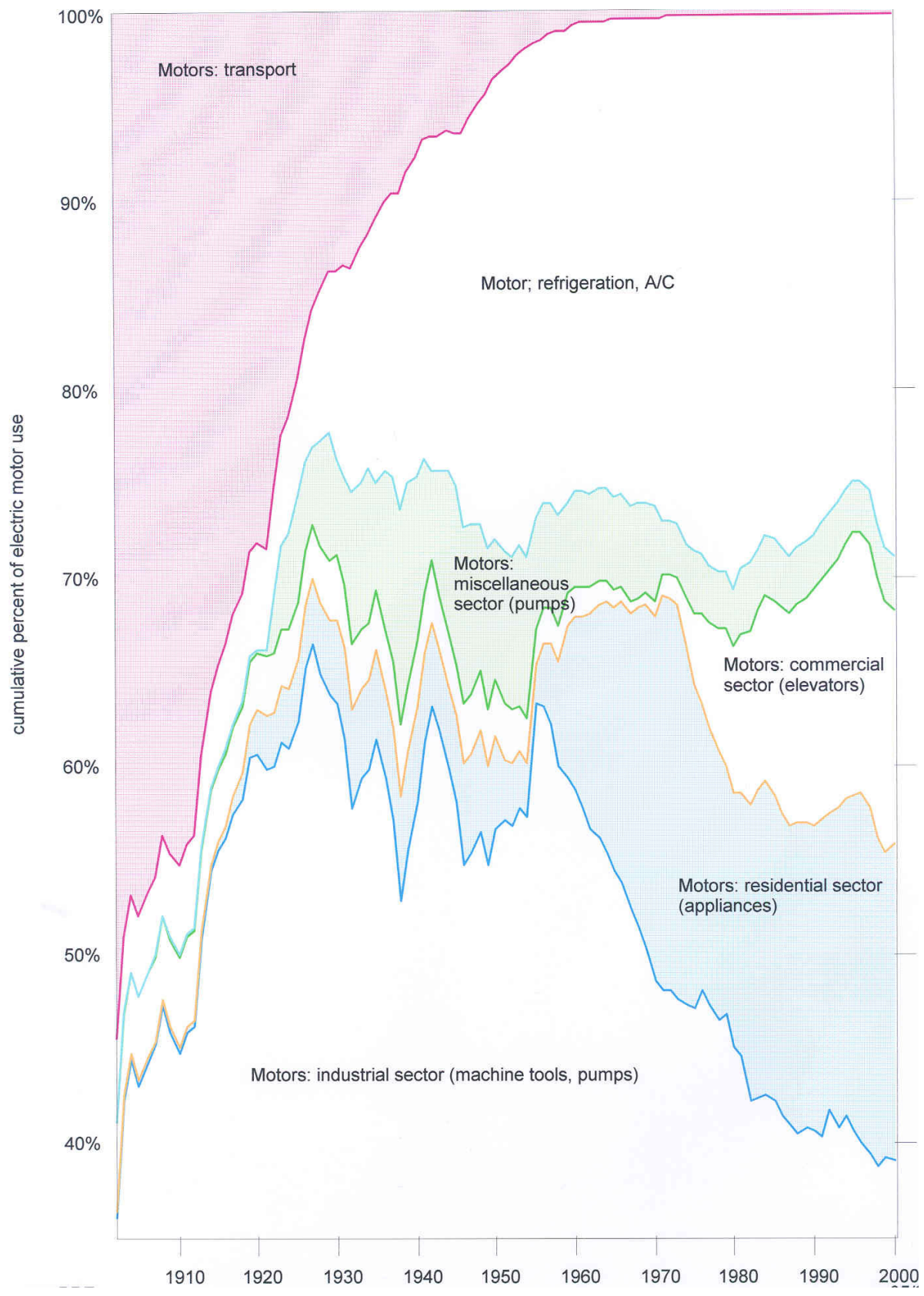

Figure 3: Electricity use in motors. Cumulative percentage of total electricity motor use, USA 1900-2000. 


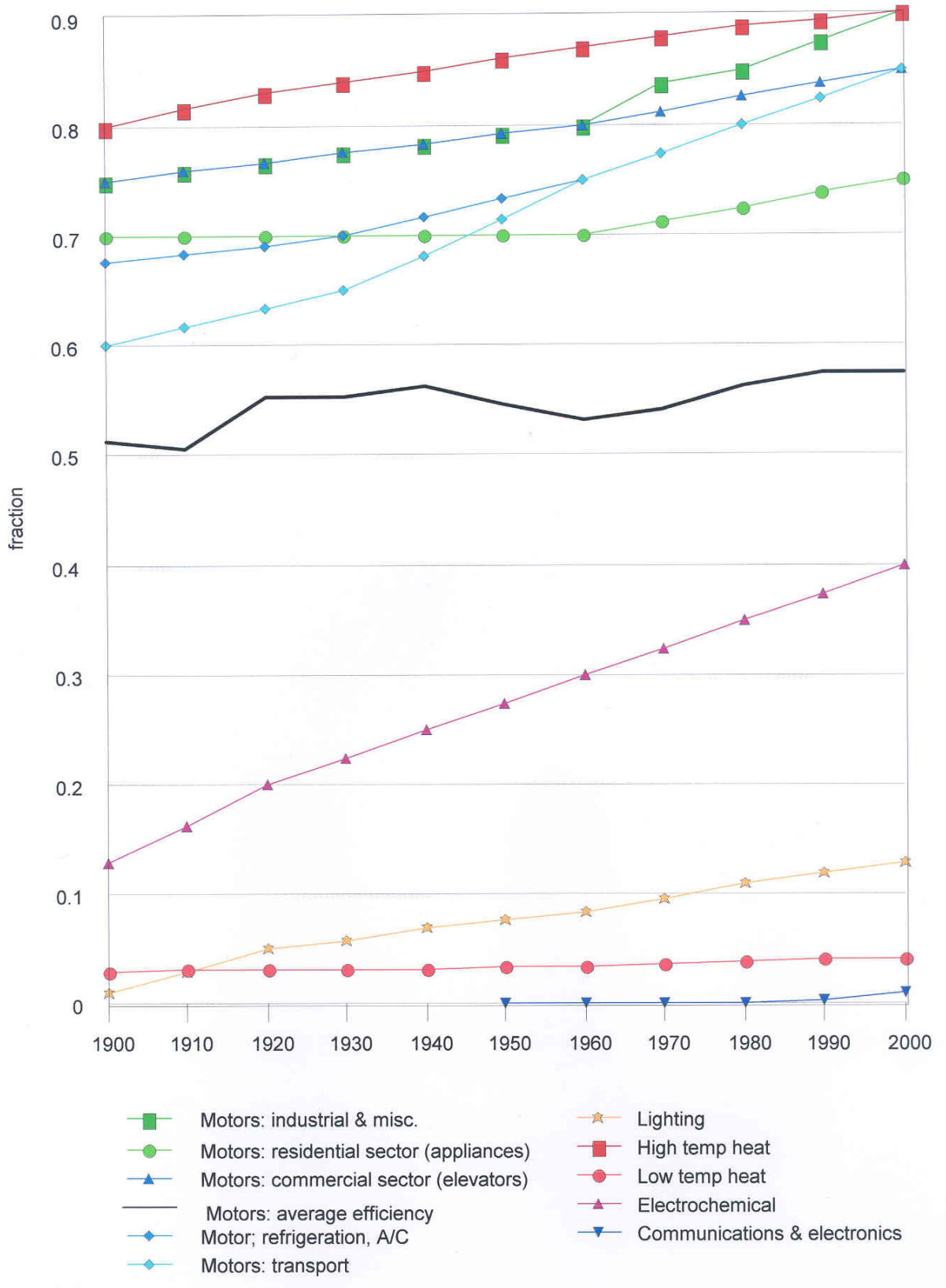

Figure 4: Efficiencies in performance. Secondary work from electricity by function, USA 1900-2000. 


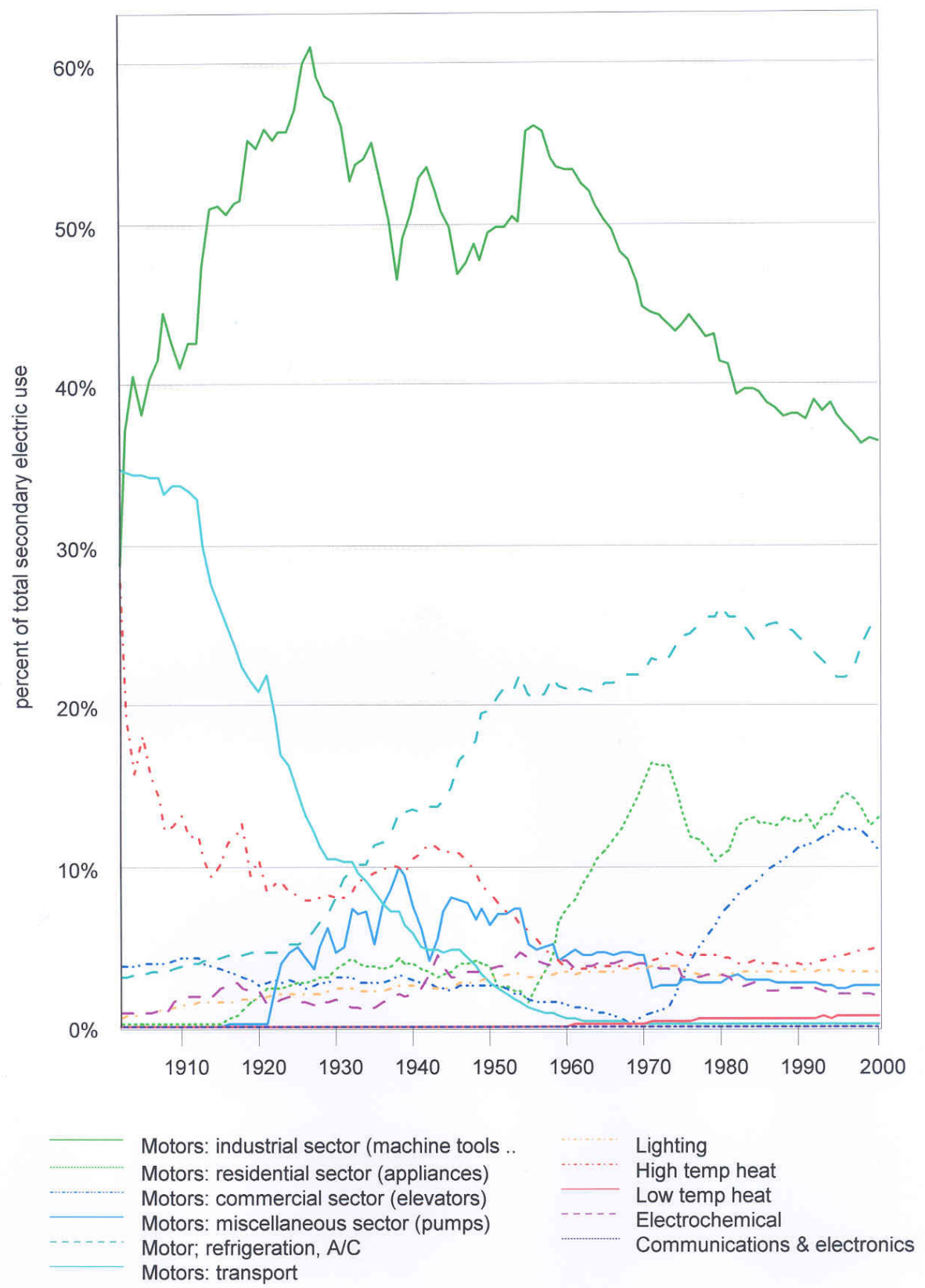

Figure 5: Secondary electrical work by function as percentage of total secondary electrical work, USA 1902-2000. 


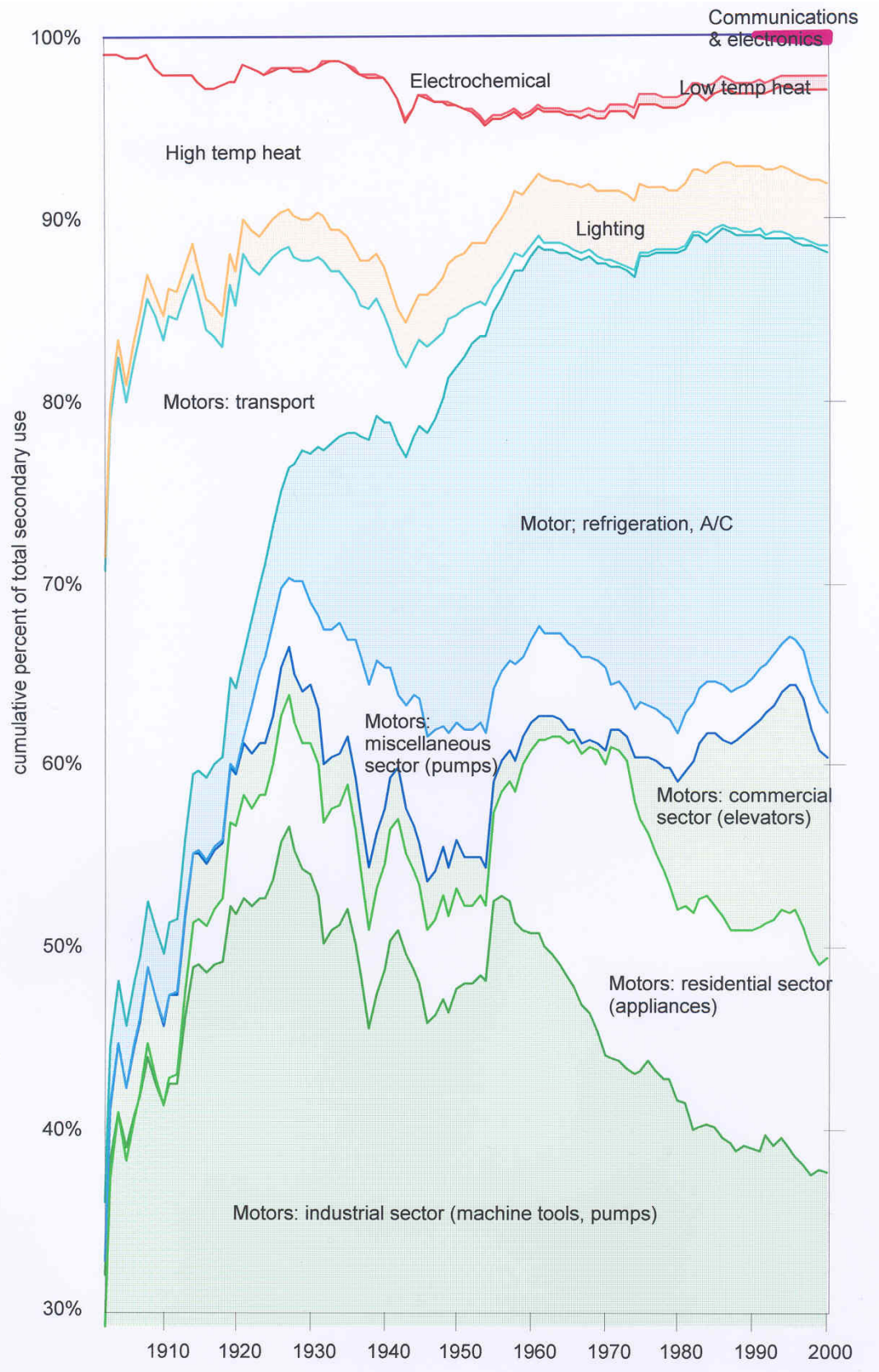

Figure 6: Secondary electrical work by function. Cumulative percentage of total secondary electrical work, USA 1902-2000. 
Table 1: Comparison of space-heating efficiencies

\begin{tabular}{lccc}
\hline \multirow{2}{*}{ Data Source } & [Ayres and Scarlott 1952] & [UNECE 1976a] & [APS 1975] \\
\cline { 2 - 4 } SYSTEM & c. 1950 - 1st law & c. 1975 - 1st law & c. 1975 - 2nd law \\
\hline Coal, oil or gas, industrial boiler & $84 \%$ & & $26 \%$ \\
Electric with heat pump (COP = 4) & $65 \%$ & $85 \%$ & $28 \%$ \\
Oil-fired furnace, domestic & $61 \%$ & $63 \%$ & $6 \%$ \\
Gas-fired furnace, domestic & $61 \%$ & $75 \%$ & $6 \%$ \\
Gas-fired water heater, domestic & & $62 \%$ & $3 \%$ \\
Coal furnace with stoker, domestic & $60 \%$ & & $6 \%$ \\
Electric with heat pump (COP = 3) & $49 \%$ & & $4 \%$ \\
Hand-fired coal furnace, domestic & $42 \%$ & & $2 \%$ (est.) \\
Wood-burning stove & $25 \%$ & $75 \%$ & NA \\
Electric heat for cooking & & $20 \%$ & NA \\
Open fireplace & $9 \%$ & NA \\
\hline
\end{tabular}

Table 2: Production of ethylene and acetylene in the US

\begin{tabular}{lccc}
\hline Year & $\begin{array}{c}\text { Acetylene } \\
\text { 000 t }\end{array}$ & $\begin{array}{c}\text { Ethylene } \\
\text { 000 t }\end{array}$ & $\begin{array}{c}\text { Acetylene } \\
\text { share \% }\end{array}$ \\
\hline 1950 & 168 & 680 & $20 \%$ \\
1955 & 268 & 1382 & $16 \%$ \\
1960 & 382 & 2471 & $13 \%$ \\
1965 & 524 & 4341 & $11 \%$ \\
1970 & 466 & 8391 & $5 \%$ \\
1975 & 211 & 9298 & $2 \%$ \\
1980 & 173 & 13003 & $1 \%$ \\
1983 & 104 & 12966 & $1 \%$ \\
\hline
\end{tabular}

Data source: [Burwell and Reister 1985] 
Table 3: Manufacturers Energy Consumption Survey Net Demand for Electricity (Summary extracted for all sectors)

\begin{tabular}{|c|c|c|c|}
\hline $\begin{array}{r}\text { Year } \\
\text { MEC source } \\
\text { Units }\end{array}$ & $\begin{array}{c}1991 \\
\text { Table A38 } \\
\text { bkwh }\end{array}$ & $\begin{array}{c}1994 \\
\text { Table A10 } \\
\text { bkwh }\end{array}$ & $\begin{array}{c}1998 \\
\text { Table N6.3 } \\
\text { bkwh }\end{array}$ \\
\hline Total Net Demand & 820.286 & 917.832 & 1025.149 \\
\hline Boiler Fuel & 9.245 & 12.467 & 8.6 \\
\hline Total Process Uses & 657.659 & 729.423 & 826.408 \\
\hline Process Heating & 71.658 & 86.383 & 106.33 \\
\hline Process Cooling and Refrigeration & 40.987 & 46.65 & 61.263 \\
\hline Machine Drive & 434.349 & 494.553 & 551.318 \\
\hline Electro-Chemical Processes & 105.663 & 96.107 & 103.615 \\
\hline Other Process Use & 5.001 & 5.73 & 3.882 \\
\hline Total Non-Process Uses & 125.751 & 144.656 & 169.347 \\
\hline Facility Heating, Ventilation, Air Conditioning & 60.301 & 68.404 & 84.678 \\
\hline Facility Lighting & 51.443 & 58.69 & 66.63 \\
\hline Facility Support & 11.522 & 14.806 & 15.495 \\
\hline Onsite Transportation & 1.298 & 1.25 & 1.427 \\
\hline Conventional Electricity Generation & -- & -- & -- \\
\hline Other Non-Process Use & 1.187 & 1.507 & 1.117 \\
\hline End Use Not Reported & 27.631 & 31.286 & 20.793 \\
\hline
\end{tabular}

Source: All data extracted from [MEC 1991; MEC 1994; MEC 1998]

Table 4: US: Electrified Class I railways

\begin{tabular}{cccc}
\hline Year & $\begin{array}{c}\text { Passengers } \\
\text { billions }\end{array}$ & $\begin{array}{c}\text { Electric power } \\
\text { bkwh }\end{array}$ & $\begin{array}{c}\text { Per capita } \\
\text { electric power } \\
\text { kWh/cap }\end{array}$ \\
\hline 1945 & 12.124 & 3.13 & 0.26 \\
1950 & 6.168 & 3.29 & 0.53 \\
1955 & 3.077 & 2.48 & 0.82 \\
\hline
\end{tabular}

Table 5. Estimates of the efficiency of electric power utilization by function, USA 1900 - 2000

\begin{tabular}{|c|c|c|c|c|c|c|c|c|}
\hline \multirow[t]{2}{*}{ Year } & \multirow[t]{2}{*}{ Lighting } & \multicolumn{2}{|c|}{ Heating } & \multirow[t]{2}{*}{ Electrolysis } & \multirow{2}{*}{$\begin{array}{c}\text { Electronic } \\
\text { signal process }\end{array}$} & \multicolumn{3}{|c|}{ Electric Motors } \\
\hline & & $\begin{array}{l}\text { High } \\
\text { Temp. }\end{array}$ & $\begin{array}{l}\text { Low } \\
\text { Temp. }\end{array}$ & & & $\begin{array}{l}\text { Refrig. } \\
\text { \& cool }\end{array}$ & $\begin{array}{c}\text { Trans- } \\
\text { port }\end{array}$ & Other \\
\hline 1900 & $1 \%$ & $80 \%$ & $3.0 \%$ & $13 \%$ & $0.001 \%$ & $70 \%$ & $60 \%$ & $70 \%$ \\
\hline 1920 & $5 \%$ & $83 \%$ & $3.2 \%$ & $20 \%$ & $0.001 \%$ & & & \\
\hline 1930 & & & & & & & $70 \%$ & \\
\hline 1940 & $7 \%$ & $85 \%$ & $3.3 \%$ & $25 \%$ & $0.001 \%$ & & & \\
\hline 1960 & $8.5 \%$ & $87 \%$ & $3.5 \%$ & $30 \%$ & $0.01 \%$ & & & $70 \%$ \\
\hline 1980 & $11 \%$ & $89 \%$ & $4.0 \%$ & $35 \%$ & $0.1 \%$ & & & \\
\hline 2000 & $13 \%$ & $90 \%$ & $4.2 \%$ & $40 \%$ & $1 \%$ & $85 \%$ & $85 \%$ & $80 \%$ \\
\hline
\end{tabular}


Table 6: Summary of electricity enduse by function in the USA, 1902-2000

\begin{tabular}{|c|c|c|c|c|c|c|c|c|c|c|c|c|c|}
\hline & & & 2000 & 1990 & 1980 & 1970 & 1960 & 1950 & 1940 & 1930 & 1920 & 1910 & 1902 \\
\hline Total & Enduse & bkwh & 3606.52 & 2816.75 & 2218.66 & 1512.51 & 777.85 & 353.29 & 162.00 & 102.44 & 50.90 & 19.10 & 5.69 \\
\hline Electrical & average secondary efficiency & $\%$ & $54.83 \%$ & $54.53 \%$ & $53.40 \%$ & $50.83 \%$ & $49.48 \%$ & $51.23 \%$ & $53.19 \%$ & $52.86 \%$ & $53.75 \%$ & $49.70 \%$ & $50.47 \%$ \\
\hline Enduse & Secondary work performed & bkwh & 1977.54 & 1536.04 & 1184.73 & 768.82 & 384.88 & 180.99 & 86.18 & 54.15 & 27.36 & 9.49 & 2.87 \\
\hline \multirow[t]{5}{*}{ Lighting } & Enduse & bkwh & 567.26 & 483.33 & 371.59 & 317.43 & 167.00 & 77.45 & 34.34 & 23.46 & 10.49 & 4.52 & $\overline{1.34}$ \\
\hline & $\%$ of total electric enduse & $\%$ & $15.73 \%$ & $17.16 \%$ & $16.75 \%$ & $20.99 \%$ & $21.47 \%$ & $21.92 \%$ & $21.20 \%$ & $22.90 \%$ & $20.60 \%$ & $23.67 \%$ & $23.61 \%$ \\
\hline & Secondary efficiency & $\%$ & $13.00 \%$ & $11.96 \%$ & $11.00 \%$ & $9.67 \%$ & $8.50 \%$ & $7.71 \%$ & $7.00 \%$ & $5.92 \%$ & $5.00 \%$ & $3.00 \%$ & $1.40 \%$ \\
\hline & Secondary work performed & bkwh & 73.74 & 57.80 & 40.88 & 30.69 & 14.20 & 5.97 & 2.40 & 1.39 & 0.52 & 0.14 & 0.02 \\
\hline & $\%$ total secondary work & $\%$ & $3.73 \%$ & $3.76 \%$ & $3.45 \%$ & $3.99 \%$ & $3.69 \%$ & $3.30 \%$ & $2.79 \%$ & $2.56 \%$ & $1.92 \%$ & $1.43 \%$ & $0.65 \%$ \\
\hline Communications & Enduse & bkwh & 286.05 & 176.39 & 111.91 & 78.36 & 46.09 & 12.65 & 5.24 & 2.01 & 0.37 & 0.14 & 0.04 \\
\hline \multirow[t]{4}{*}{ Electronics } & $\%$ of total electric enduse & $\%$ & $7.93 \%$ & $6.26 \%$ & $5.04 \%$ & $5.18 \%$ & $5.93 \%$ & $3.58 \%$ & $3.24 \%$ & $1.96 \%$ & $0.72 \%$ & $0.74 \%$ & $0.62 \%$ \\
\hline & Secondary efficiency & $\%$ & $1.00 \%$ & $0.32 \%$ & $0.10 \%$ & $0.03 \%$ & $0.01 \%$ & $0.003 \%$ & $0.001 \%$ & $0.001 \%$ & $0.001 \%$ & $0.001 \%$ & $0.001 \%$ \\
\hline & Secondary work performed & bkwh & 2.86 & 0.56 & 0.11 & 0.02 & 0.0046 & 0.0004 & 0.00 & 0.00 & & & \\
\hline & $\%$ total s & $\%$ & $0.14 \%$ & $0.04 \%$ & $0.01 \%$ & $0.00 \%$ & $0.000 \%$ & & & & & & \\
\hline \multirow[t]{5}{*}{ Electrolytic } & Enduse & bkwh & 105.35 & 105.49 & 119.25 & 102.38 & 56.57 & 25.43 & 7.97 & 4.36 & 3.28 & 1.20 & 0.20 \\
\hline & $\%$ of total electric enduse & $\%$ & $2.92 \%$ & $3.75 \%$ & $5.37 \%$ & $6.77 \%$ & $7.27 \%$ & $7.20 \%$ & $4.92 \%$ & $4.25 \%$ & $6.44 \%$ & $6.30 \%$ & $3.59 \%$ \\
\hline & Secondary efficiency & $\%$ & $40.00 \%$ & $37.42 \%$ & $35.00 \%$ & $32.40 \%$ & $30.00 \%$ & $27.39 \%$ & $25.00 \%$ & $22.36 \%$ & $20.00 \%$ & $16.12 \%$ & $13.57 \%$ \\
\hline & work performed & bkwh & 42.14 & 39.47 & 41.74 & 33.18 & 16.97 & 6.96 & 1.99 & 0.97 & 0.66 & 0.19 & 0.03 \\
\hline & $\%$ total s & $\%$ & $2.13 \%$ & $2.57 \%$ & $3.52 \%$ & $4.32 \%$ & $4.41 \%$ & $3.85 \%$ & $2.31 \%$ & $1.80 \%$ & $2.40 \%$ & $2.04 \%$ & $0.97 \%$ \\
\hline High & Enduse & bkwh & 116.53 & 70.95 & 61.93 & 37.96 & 17.85 & 18.75 & 11.17 & 5.47 & 3.57 & 1.56 & 1.01 \\
\hline Temperature & $\%$ of total electric enduse & $\%$ & $3.23 \%$ & $2.52 \%$ & $2.79 \%$ & $2.51 \%$ & $2.29 \%$ & $5.31 \%$ & $6.89 \%$ & $5.34 \%$ & $7.02 \%$ & $8.18 \%$ & $17.71 \%$ \\
\hline \multirow[t]{3}{*}{ Heat } & Secondary efficiency & $\%$ & $90.00 \%$ & $89.50 \%$ & $89.00 \%$ & $87.99 \%$ & $87.00 \%$ & $85.99 \%$ & $85.00 \%$ & $83.99 \%$ & $83.00 \%$ & $81.49 \%$ & $80.30 \%$ \\
\hline & work performed & bkwh & 104.88 & 63.50 & 55.12 & 33.41 & 15.53 & 16.12 & 9.49 & 4.60 & 2.97 & 1.27 & 0.81 \\
\hline & $\%$ total s & $\%$ & $5.30 \%$ & $4.13 \%$ & $4.65 \%$ & $4.34 \%$ & $4.03 \%$ & $8.91 \%$ & $11.02 \%$ & $8.49 \%$ & $10.84 \%$ & $13.42 \%$ & $28.17 \%$ \\
\hline Low & Enduse & bkwh & 392.63 & 249.70 & 198.85 & 73.34 & 19.62 & 7.02 & 1.72 & 0.61 & & & \\
\hline Temperature & $\%$ of total electric enduse & $\%$ & $10.89 \%$ & $8.86 \%$ & $8.96 \%$ & $4.85 \%$ & $2.52 \%$ & $1.99 \%$ & $1.06 \%$ & $0.60 \%$ & & & \\
\hline \multirow[t]{3}{*}{ Heat } & efficiency & $\%$ & $4.20 \%$ & $4.10 \%$ & $4.00 \%$ & $3.74 \%$ & $3.50 \%$ & $3.40 \%$ & $3.30 \%$ & $3.25 \%$ & $3.20 \%$ & $3.10 \%$ & $3.02 \%$ \\
\hline & Second: & bkwh & 16.49 & 10.23 & 7.95 & 2.74 & 0.69 & 0.24 & 0.06 & 0.02 & & & \\
\hline & $\%$ total s & $\%$ & $0.83 \%$ & $0.67 \%$ & $0.67 \%$ & $0.36 \%$ & $0.18 \%$ & $0.13 \%$ & $0.07 \%$ & $0.04 \%$ & & & \\
\hline \multirow{5}{*}{$\begin{array}{l}\text { All Heating } \\
\text { (high and low) }\end{array}$} & Enduse & bkwh & 509.16 & 320.64 & 260.79 & 111.30 & 37.47 & 25.76 & 12.89 & 6.08 & 3.57 & 1.56 & $\overline{1.01}$ \\
\hline & $\%$ of total electric enduse & $\%$ & $14.12 \%$ & $11.38 \%$ & $11.75 \%$ & $7.36 \%$ & $4.82 \%$ & $7.29 \%$ & $7.96 \%$ & $5.94 \%$ & $7.02 \%$ & $8.18 \%$ & $17.71 \%$ \\
\hline & Secondary & $\%$ & $23.84 \%$ & $22.99 \%$ & $24.19 \%$ & $32.48 \%$ & $43.28 \%$ & $63.50 \%$ & $74.09 \%$ & $75.87 \%$ & $82.99 \%$ & $81.49 \%$ & $80.30 \%$ \\
\hline & ork performed & bkwh & 121.37 & 73.73 & 63.07 & 36.15 & 16.22 & 16.36 & 9.55 & 4.62 & 2.97 & 1.27 & 0.81 \\
\hline & $\%$ total se & $\%$ & $6.14 \%$ & $4.80 \%$ & $5.32 \%$ & $4.70 \%$ & $4.21 \%$ & $9.04 \%$ & $11.08 \%$ & $8.53 \%$ & $10.84 \%$ & $13.42 \%$ & $28.17 \%$ \\
\hline Motors - & Enduse & bkwh & 524.10 & 416.30 & 355.27 & 191.23 & 89.14 & 37.71 & 11.41 & 3.35 & 0.48 & 0.21 & 0.05 \\
\hline \multirow{2}{*}{$\begin{array}{r}\text { Refrigeration } \\
\text { and }\end{array}$} & $\%$ of total electric enduse & $\%$ & $14.53 \%$ & $14.78 \%$ & $16.01 \%$ & $12.64 \%$ & $11.46 \%$ & $10.67 \%$ & $7.04 \%$ & $3.27 \%$ & $0.95 \%$ & $1.08 \%$ & $0.86 \%$ \\
\hline & Seconda & $\%$ & $85.00 \%$ & $83.37 \%$ & $81.76 \%$ & $80.19 \%$ & $78.65 \%$ & $77.14 \%$ & $75.65 \%$ & $74.20 \%$ & $72.77 \%$ & $71.37 \%$ & $70.27 \%$ \\
\hline \multirow[t]{2}{*}{ airconditioning } & vork performed & bkwh & 445.48 & 347.05 & 290.48 & 153.35 & 70.10 & 29.09 & 8.63 & 2.48 & 0.35 & 0.15 & 0.03 \\
\hline & $\%$ total se & $\%$ & $22.53 \%$ & $22.59 \%$ & $24.52 \%$ & $19.95 \%$ & $18.21 \%$ & $16.07 \%$ & $10.01 \%$ & $4.59 \%$ & $1.29 \%$ & $1.55 \%$ & $1.20 \%$ \\
\hline Motors - & Enduse & bkwh & 5.28 & 4.75 & 3.24 & 3.11 & 3.07 & 7.68 & 7.77 & 9.13 & 9.32 & 5.29 & 1.69 \\
\hline \multirow[t]{4}{*}{ Transport } & $\%$ of total electric enduse & $\%$ & $0.15 \%$ & $0.17 \%$ & $0.15 \%$ & $0.21 \%$ & $0.39 \%$ & $2.17 \%$ & $4.80 \%$ & $8.91 \%$ & $18.31 \%$ & $27.69 \%$ & $29.66 \%$ \\
\hline & Secondary efficiency & $\%$ & $85.00 \%$ & $83.49 \%$ & $82.01 \%$ & $80.56 \%$ & $79.13 \%$ & $77.73 \%$ & $76.35 \%$ & $75.00 \%$ & $69.62 \%$ & $64.63 \%$ & $60.90 \%$ \\
\hline & ork performed & bkwh & 4.49 & 3.97 & 2.66 & 2.51 & 2.43 & 5.97 & 5.93 & 6.85 & 6.49 & 3.42 & 1.03 \\
\hline & $\%$ total se & $\%$ & $0.23 \%$ & $0.26 \%$ & $0.22 \%$ & $0.33 \%$ & $0.63 \%$ & $3.30 \%$ & $6.89 \%$ & $12.65 \%$ & $23.72 \%$ & $36.01 \%$ & $35.79 \%$ \\
\hline Motors - & Enduse & bkwh & 1609.32 & 1309.84 & 996.61 & 708.69 & 378.52 & 166.62 & 82.38 & 54.06 & 23.39 & 6.18 & 1.36 \\
\hline \multirow[t]{4}{*}{ 'Unallocated } & $\%$ of total electric enduse & $\%$ & $44.62 \%$ & $46.50 \%$ & $44.92 \%$ & $46.86 \%$ & $48.66 \%$ & $47.16 \%$ & $50.85 \%$ & $52.77 \%$ & $45.95 \%$ & $32.33 \%$ & $23.95 \%$ \\
\hline & Secondary efficiency & $\%$ & $80.00 \%$ & $77.37 \%$ & $74.83 \%$ & $72.38 \%$ & $70.00 \%$ & $70.00 \%$ & $70.00 \%$ & $70.00 \%$ & $70.00 \%$ & $70.00 \%$ & $70.00 \%$ \\
\hline & Secondary work performed & bkwh & 1287.45 & 1013.47 & 745.79 & 512.92 & 264.96 & 116.63 & 57.67 & 37.84 & 16.37 & 4.32 & 0.95 \\
\hline & $\%$ total secondary work & $\%$ & $65.10 \%$ & $65.98 \%$ & $62.95 \%$ & $66.72 \%$ & $68.84 \%$ & $64.44 \%$ & $66.92 \%$ & $69.88 \%$ & $59.84 \%$ & $45.54 \%$ & $33.22 \%$ \\
\hline \multirow{5}{*}{$\begin{array}{l}\text { All Motors - } \\
\text { (specific and } \\
\text { unallocated) }\end{array}$} & Enduse & bkwh & 2138.69 & 1730.89 & 1355.12 & 903.03 & 470.72 & 212.01 & 101.56 & 66.54 & 33.20 & 11.67 & 3.10 \\
\hline & $\%$ of total electric enduse & $\%$ & $59.30 \%$ & $61.45 \%$ & $61.08 \%$ & $59.70 \%$ & $60.52 \%$ & $60.01 \%$ & $62.69 \%$ & $64.95 \%$ & $65.22 \%$ & $61.10 \%$ & $54.47 \%$ \\
\hline & Secondary efficiency & $\%$ & $81.24 \%$ & $78.83 \%$ & $76.67 \%$ & $74.06 \%$ & $71.70 \%$ & $71.55 \%$ & $71.12 \%$ & $70.90 \%$ & $69.93 \%$ & $67.59 \%$ & $65.05 \%$ \\
\hline & Secondary work performed & bkwh & 1737.42 & 1364.49 & 1038.93 & 668.78 & 337.49 & 151.69 & 72.23 & 47.17 & 23.22 & 7.89 & 2.02 \\
\hline & $\%$ total secondary work & $\%$ & $87.86 \%$ & $88.83 \%$ & $87.69 \%$ & $86.99 \%$ & $87.69 \%$ & $83.81 \%$ & $83.82 \%$ & $87.11 \%$ & $84.85 \%$ & $83.11 \%$ & $70.21 \%$ \\
\hline
\end{tabular}




\section{APPENDIX: Data tables}

This Appendix consists of the complete data set expansion of all functional electricity uses discussed and derived in the text. Bold face and bold italic entries were copied directly from specific published sources as cited in either the footnotes to the specific table or directly in the main text. Authors' estimates are given in plain italic; interpolations and other calculated values in normal face. The column heading shows the calculation when anything other than interpolation, extrapolation has occurred.

Data sources have been abbreviated in the tables. They are listed below, preceded by their citation in the main reference list and followed by their Table abbreviation code.

[USGS annual] Minerals Yearbooks (MYB)

[USDOEEIA annual] Annual Energy Review (AER)

[USDOC 1992a] Business Statistics - various years (BEA)

[CEN 1990; CEN 1991; CEN 1992] Chemical \& Engineering News (C\&EN)

[USBuMines monthly; USGS monthly] Mineral Commodities Summaries (MinC)

[Schurr and Netschert 1960] Energy in the American Economy (S\&N)

[Lowenheim and Moran 1975] Faith, Keyes and Clark's 'Industrial Chemicals"' (Lowenheim \& Moran)

[USCensus 1975] Historical Statistics 1970 (shown in italic as HIST)

[MEC 1991; MEC 1994; MEC 1998] Manufacturing Energy Consumption Surveys 1991, 1994, 1998 (MEC)

[USEPA 1971; USEPA 1976d] "Atmospheric Emissions from Chlor-Alkali Manufacture" (EPA 1971)

[SRI 1989b] "Chlorine \& Alkali Chemicals" (SRI 1989a)

[SRI 1989a] "SRI PEP Yearbook 1989" (SRI 1989 b)

[Burwell and Reister 1985] "Electricity Use \& Use Trends in the Production of Chemicals" (Burwell \& Reister 1985)

[Myers 1974] "Energy Consumption in Manufacturing" (Myers et al. 1974)

[Considine et al 2000] "The Industrial Ecology of Steel" (Considine 2001)

[REC 1997] Residential Energy Consumption=Household Energy Consumption Survey (REC) 